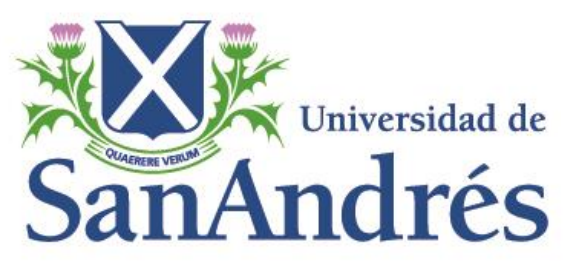

"State Capacity and the Quality of Policies. Revisiting the Relationship between Openness and Government Size"

Por María Franco Chuaire (Banco Interamericano de Desarrollo), Carlos Scartascini (Banco Interamericano de Desarrollo) y Mariano Tommasi (Universidad de San Andrés).

D.T.: $\mathbf{N}^{\circ} 115$

Noviembre 2014

Vito Dumas 284, B1644BID, Victoria, San Fernando, Buenos Aires, Argentina Teléfono 4725-7020, Fax 4725-7010

Email: economia@udesa.edu.ar 


\title{
State Capacity and the Quality of Policies \\ Revisiting the Relationship between Openness and Government Size
}

\author{
María Franco Chuaire (Inter-American Development Bank) \\ Carlos Scartascini (Inter-American Development Bank) \\ Mariano Tommasi (Universidad de San Andrés)
}

\begin{abstract}
Countries with different levels of state capacity have access to different sets of policies. In particular, countries with strong state capabilities are able to draw from a broader menu of policies, and pick and successfully implement those policies that best suit the nature of their challenges. In the case of exposure to trade related risk, the literature has usually considered that only one type of policies -those increasing government size- can help to overcome the challenge. However, there are a number of policies that can mitigate trade-induced risks, many of which do not have the necessary implication of increasing public spending. Yet, many such policies require governmental capabilities not available to any country. For that reason, the relationship between openness and the size of government might be mediated by the capabilities of states. The empirical analysis in this paper shows exactly that.
\end{abstract}

Keywords: Government capabilities, Quality of policies, Openness, Government size

Contact Author Information:

Carlos Scartascini

Research Department, Inter-American Development Bank

1300 New York Ave, NW

Washington, DC 20577

carlossc@iadb.org 


\section{Introduction}

The issue of government capabilities or, more broadly, of state capacity is a complex one, and it has given rise to important analytical, measurement, and evaluation efforts, as well as lively methodological debates. The concept of "state capacity" is very salient in studies of economic development, and its presence or absence has been associated with development successes and failures. Countries with strong state capabilities are able to draw from a broader menu of policies, and pick and successfully implement those policies that best suit the nature of their challenges. Countries with low state capacity have difficulties in implementing complex economic policies.

One out of the many challenges countries face are the external, trade-induced, shocks. Countries that are more open, or that are more vulnerable to terms of trade shocks due to the structure of their economy, have to find ways to reduce the incidence and impact of those shocks. One way for countries to respond is by a variety of government programs and policies, which include welfare programs, and public employment, among others, that may affect public sector size (Cameron 1978, Katzenstein, 1985, Rodrik 1998). In spite of a long literature making the connection, the logic tying openness and trade-induced potential shocks to public spending may not be necessarily right for every country.

In this paper we build upon the ample literature that shows the relevance of state capacity (or government capabilities) for the selection and implementation of public policies to argue that there are a variety of different policy responses to the additional economic volatility induced by trade openness, not all of which imply increasing public spending (or increasing spending as much). ${ }^{1}$ Which policy is available to a specific country depends on its capabilities. For example,

\footnotetext{
${ }^{1}$ The fact that countries may react differently to economic integration is not new. See for example Bates, et al (1991) and Garrett (1998a, 1998b, 2001).
} 
while almost any government can reduce volatility by increasing its size through hiring more people, countries with stronger governmental capabilities might address such challenges by more efficient and less costly means by introducing more suitable macro, fiscal, micro, and social policies.

We do not argue about which policies each country will choose (which depends on the details of its economic structure and social fabric, as well as details of short-term politics) but about the fact that given a strong link between state capacity and the set of policies each country can pursue, there are some countries that can insulate their economy more efficiently to external shocks than others. ${ }^{2}$ This argument holds in the data. As government capabilities increase, and hence the set of policy options at the disposal of authorities increases, the effect of openness on government size decreases and even dissipates. Therefore, our results indicate that the effect of openness on government consumption is mediated by the quality of government institutions. This result holds in the cross-section, panel, in instrumental variables regressions, across different samples, and is robust to different specifications. Also, we cannot uncover the same results when we run placebo regressions.

This finding about the conditional effect of openness on expenditures says very little about the overall size of the government for each country, and it does not preclude the fact that governments with higher capabilities may be able to pursue other policy objectives which have an effect on size (e.g., they may be able to have higher infrastructure spending or pursue more redistributive policies).

The results in the paper constitute a step in an agenda attempting to build bridges between the study of institutions and policymaking in contexts of high and of low government

\footnotetext{
${ }^{2}$ In this sense, our reduced-form approach is reminiscent of that in the seminal study of the impact of bureaucratic capabilities on growth by Evans and Rauch (1999).
} 
capabilities, under a view that highlights the importance of state capacities for economic development. ${ }^{3}$ These results engage with important discussions in both comparative politics and international political economy, and open the door to incorporating the notion of state capacity more explicitly into theoretical and empirical models. ${ }^{4}$

The paper proceeds as follows. The next section conceptualizes the notion of state capacity and presents the related literature. Since we apply our framework to the specific relationship between openness and size of the government, Section 3 briefly discusses the corresponding literature. It highlights the original discussion brought forward by Rodrik (1998), as well as the extensions, clarifications, and criticisms it has received. Section 4 argues about the relationship between government capabilities (or state capacity) and the vector of risk-reducing policies that each type of country can access. The measures of state capacity, the empirical analysis, including the robustness and placebo exercises, and the discussion of the results are presented in Section 5. Section 6 concludes.

\section{State Capacity}

\footnotetext{
${ }^{3}$ It complements a related literature on the study of institutions and policymaking in contexts of different degrees of institutionalization. See Scartascini and Tommasi (2012) for a model explaining institutionalization as an equilibrium political outcome, and Caruso, et al (2013) for an empirical study arguing that standard results on the effects of political constitutions on fiscal outcomes (à la Persson and Tabellini, 2003) apply only for countries with high levels of institutionalization.

${ }^{4}$ Our results complement a longer tradition of articles dealing with policymaking in the context of differing capabilities. For example, while Bates, et al (1991) identify the ability to offer transfers to compensate for risk as a determinant of openness, we argue here that for a given level of openness, different levels of government capabilities allow access to different insurance mechanisms. Evans and Rauch (1999) work on bureaucratic quality and growth opened a broad research agenda (such as Hamm and King 2010) showing how different capabilities could lead to different policies and economic outcomes.
} 
The issue of government capabilities or, more broadly, of state capacity is a complex one, and it has given rise to important analytical, measurement, and evaluation efforts, as well as lively methodological debates. ${ }^{5}$ The concept of "state capacity" is very salient in studies of economic development, and its presence or absence has been associated with development successes and failures. It has many dimensions, such as coercive or military capacity, fiscal or extractive capacity, administrative or implementation capacity, and legal capacity. ${ }^{6}$ The emphasis on each of its dimensions depends on the issue at hand.

The type of economic and social policy implementation capabilities we focus on in this paper come closer to the notion of administrative or implementation capacity. This dimension, perhaps the most widely referred to in the literature (Cingolani, 2013), is largely rooted in the Weberian tradition regarding the modern state and the existence of a professional and insulated bureaucracy. The bureaucratic/administrative dimension of state capacity has been emphasized by classic authors such as Huntington (1968) and Skocpol (1979). Weaver and Rockman (1993) conceive state capacities as policymaking capabilities, including the capacity to effectively implement policies. In Knutsen (2013) state capacity is understood as the successful implementation of public policies through an efficient rule-following bureaucracy.

The notion of capabilities we have in mind also relates to the idea of the "transformative" capacities of states, conceived as "the ability of a state to adapt to external shocks and pressures by generating ever-new means of governing the process of industrial change' (Weiss, 1998). This aspect is also present in the work of Evans (1989 and 1995) who refers to embedded autonomy, a combination of administrative insulation power and a certain level of state embededdness in the productive structure. According to Rueschmeyer and Evans (1995), the

\footnotetext{
${ }^{5}$ See, for instance, the debate in the journal Governance surrounding an article by Francis Fukuyama (2013): http://governancejournal.net/2013/03/04/fukuyama-asks-what-is-governance/.

${ }^{6}$ See Cingolani (2013) for a very comprehensive recent survey of the concept and its measurement.
} 
effectiveness of state intervention in the economy depends upon a capable bureaucracy and good coordination and coherence among state organizations.

The question of where does state capacity come from has also received substantial attention. Cingolani (2013) provides a review of studies on the determinants of state capacity, from the historical accounts of state formation processes and its impact on subsequent types of administrative infrastructure, to the more recent emphasis on the incentives to invest in state capacity. A common theme among these various arguments and strands is that capacity is a multidimensional object that accumulates slowly over time, as a function of various investments. $^{7}$ These governmental capabilities do not evolve overnight, and they cannot be constructed by fiat by writing an institutional reform law. They are the outcome of actions of key political players over time, in the context of country-specific political equilibria (Besley and Persson, 2009; Enríquez and Centeno, 2012). ${ }^{8}$

Not surprisingly, the measures of state capacity found in the literature are quite varied, some of them aiming at capturing state capacity in a broad generic way, others acknowledging the existence of several aspects or dimensions, and trying to measure each of them. We discuss the specific measures in the empirical section. In that section, we also show that because countries with strong state capabilities might be able to draw from a broader menu of policies and implement them more successfully, they may be able to adjust more efficiently to the challenges. One of those challenges is to deal with the risks induced by openness and trade volatility, which is the policy area we have chosen to evaluate.

\section{More Open Economies and Bigger Governments}

\footnotetext{
${ }_{8}^{7}$ Skocpol and Finegold (1982) argument about the US bureaucracy also fits well here.

${ }^{8}$ The very nature of democracies implies alternation in power, and if power is going to switch hands, an important element of intertemporal cooperation is crucial for the buildup of government capabilities (IDB, 2005; Stein and Tommasi, 2007).
} 
The so called "compensation hypothesis" is an important benchmark for the analysis of the effects of trade openness on domestic policy. Cameron (1978) was the first to observe that trade openness was, at that time, one of the most important determinants of government size in OECD countries. Katzenstein (1985) argued that small European states complemented their international liberalization with strategic domestic compensation aimed at countering its harmful effects. The empirical pattern relating trade openness with larger governments was extended to a broader international sample by Rodrik (1998). In Rodrik's analysis, the positive association was not limited to the cross section; on average, international trade and public sectors had tended to grow together. ${ }^{9}$

Some authors have reversed the causal arrow, claiming that the political sustainability of globalization in open societies requires a thick compensating welfare state. This "reverse compensation hypothesis" argues that that once a country has a large welfare state, trade liberalization becomes more likely. ${ }^{10}$

The discussion on the relationship between trade openness and the size of the public sector is embedded in a broader discussion about the effects of "globalization", including financial openness and integration (Garrett 1998b, 2001). The core issue is whether governments respond to the challenges of globalization with policy choices that are oriented more towards cutting costs (efficiency hypothesis) or protecting people's welfare (compensation hypothesis)

\footnotetext{
${ }^{9}$ Alesina and Wacziarg (1998) confirmed the correlation but argue that country size is a mediating factor: smaller countries have larger shares of government consumption and tend to be more open to trade. Ram (2009) revisited this idea with panel data, and concluded that "the estimates are consistent with the possibility of a direct link between openness and government size along the lines suggested by Rodrik (1998)." Epifani and Gancia (2009) also find that the correlation between government size and openness is robust to the inclusion of country size. Adserà and Boix (2002) confirm the compensation hypothesis, but find democracy to be an important intermediary: as openness to international trade increases, the size of the public sector increases in democratic regimes.

${ }^{10}$ See for instance Garrett (1998a), Adserà and Boix (2002), Hays, et al (2005), Scheve and Slaughter (2007), and Martin and Steiner (2013). Noorruddin and Rudra (2014) show that less developed countries use public employment to protect citizens from the economic insecurities coming from the exposure to global markets. However, the type of public employment used, focused on civil services and administration, tends to favor the politically prominent groups that are those that show the most support for openness.
} 
(Avelino, et al, 2001). In the context of that discussion there are related efforts looking at the effects of financial openness, often thought to limit the scope of government, as postulated by the "efficiency hypothesis." "11

Various studies have delved deeper into the microfoundations of the demand and supply of "compensation", looking at a more disaggregated level of policies, (including varieties of welfare states) and different politics. For instance, studies such as Rehm (2009), Baker (2008), and Walter (2010) study individual level demand for redistribution in the context of open economies. Burgoon (2001) looks at the level of specific government programs and argues that each one can be a more or less significant source of compensation, and hence is subject to different politics. Mares (2004 and 2005) argues that the individual demand for different types of social policy depends on relative risk exposure across sectors, as well as on deeper political economy considerations.

Despite all these rich and nuanced considerations, at the macro level, the correlation between trade openness and government size has become fairly established, to the point that important studies exploring the determinants of the size of government commonly include openness as a control. ${ }^{12}$

For concreteness, we focus here on the compensation hypothesis as stated by Rodrik (1998) in order to anchor our argument on alternative policies to deal with trade-induced economic insecurity and on the conditional effect of state capacity on the ability to implement such policies.

\footnotetext{
${ }^{11}$ Some of the works that have incorporated the impact of financial openness into the analysis include, Garrett (2001), Avelino, et al (2005), Kittel and Winner (2005), Liberati (2007), Kimakova (2009), and Erauskin (2011). Similarly, Gemmell, et al (2008) have tried to explore the effects of globalization by focusing on FDI, as opposed to trade openness.

${ }^{12}$ Such works include Milesi-Ferreti, et al (2002), Persson and Tabellini (2003), Mueller (2003), Blume, et al (2009), and Rockey (2012), among many others.
} 
Having identified a robust correlation between openness to trade and the size of the public sector, Rodrik postulates that the main reason for that connection is "compensation" for higher risk exposure. In his view, more open economies have a greater exposure to risk from the turbulence of world markets, and government spending serves an insulation function. ${ }^{13} \mathrm{He}$ considers the government sector as the "safe" sector of the economy, especially compared to tradables; hence, the government can mitigate the shocks from international markets by taking command of a larger share of the economy's resources.

Rodrik postulates a simple framework with three sectors: private tradables, private nontradables, and the government. Assuming that a representative household owns streams of income from all sectors, a higher share of (permanent) government consumption can provide some ex ante insurance to external risk. Rodrik asks when (i.e., under what conditions) "will it be optimal for the government to reduce risk in this fashion?" (p. 1011). Reducing risk by enlarging the government is optimal in the stylized set-up presented by Rodrik; a key assumption there is that the decision on how many resources to allocate to the public and to the private sectors is made before the realization of the terms of trade shocks. Given standard assumptions on production and utility functions and the fact that the government is the "safe asset," in such a set-up it is optimal to allocate more resources to the government, the higher the (trade-induced) risk in the private sector. In this way, the model generates the correlation between openness and spending — or more generally, the correlation between external risk (openness times terms of trade volatility) and spending.

\section{Openness, State Capacity, and the Size of Government}

\footnotetext{
${ }^{13} \mathrm{He}$ observes not only that there is a positive and robust partial correlation between openness and the scope of government, but also that the relationship between openness and government size is strongest when terms of trade risk is higher.
} 
The set of policy instruments available in Rodrik's framework is a rather restrictive one. In the real world, there is a large set of potential macro, micro, and social policies that might mitigate or alleviate the effects of external shocks, and many of them do not have obvious budgetary implications. In terms of Rodrik's model, some of those policy instruments might be equivalent to allowing part of the adjustment to take place after the realization of the shock; others are equivalent to finding cheaper ways to insure ex ante. Some operate at the stage of softening the macroeconomic implication of those shocks, others at the level of permitting more efficient and less costly microeconomic adjustment, and others at providing more efficient and less costly social protection. Many of the potential policies might be relatively demanding in terms of government capabilities, and hence not equally available to all polities. We list below some of the policies that help mitigate or alleviate the effects of external shocks, explaining why many of them require a capable public sector (in particular a high-quality bureaucracy) for their implementation.

Within the vector of policies to cope with external instability, we start referring to a number of different macroeconomic policies that have been proposed and used as ways to cope with various sources of macroeconomic volatility. One set of policies particularly relevant with regards to external shocks are exchange rate policies. ${ }^{14}$ It is often argued that flexible exchange rates provide better insulation to trade shocks than fixed exchange rates. ${ }^{15}$ As exchange rate choices do not map very easily into the size of the public sector, they constitute one example of non-budgetary insulation. Since the effective implementation of a flexible exchange rate regime requires some administration that might be institutionally more demanding than a fixed regime,

\footnotetext{
${ }^{14}$ Gelos and Ustyugova (2012) provide another macroeconomic example in which government capabilities permit better adjustment to terms of trade shocks; they show that countries with more independent central banks and higher governance scores have contained the impact of commodity price shocks better.

${ }^{15}$ For instance, Broda and Tille (2003) find that countries with a flexible exchange rate tend to experience much milder contractions in output than their counterparts with fixed exchange rate regimes.
} 
countries with weak institutions tend to choose fixed exchange rate regimes as way of pumping up their scarce credibility. ${ }^{16}$

Different types of fiscal policies also help mitigate the exposure to the risks associated with international economic integration. For instance, well-designed fiscal rules may alleviate the effects of terms of trade volatility by contributing to reduce procyclical fiscal policies and related "Dutch Disease" problems (UNCTAD, 2011). But the ability to properly implement adequate fiscal policies is not so readily available to any country. Various studies have documented differences in the quality of fiscal policy across countries (Gavin and Perotti, 1997; López, et al, 2010; Céspedes and Velasco, 2013), and several studies have established that the ability to implement proper fiscal policies (and in particular, policies that facilitate coping with shocks) is dependent upon institutional capabilities. Calderón, et al (2012) find that fiscal and monetary policies tend to be significantly procyclical in countries with weaker policymaking capabilities. Filc and Scartascini (2012) find that countries with better implementation capabilities are able to design better fiscal frameworks. Céspedes and Velasco (2013) find that improvements in institutional quality have led commodity-rich countries to be more able to respond adequately to commodity price shocks. Notice that higher government capacity allows implementing fiscal policies that adjust better to shocks, a form of ex post "insurance", as opposed to blindly increasing spending as a form of ex ante insurance, which would be likely the choice for those who cannot access better policies.

In addition to the fiscal policy framework, the depth of financial markets can significantly influence the way in which economies react to terms of trade volatility. In particular, higher financial development can help mitigate the effect of terms of trade volatility on consumption

\footnotetext{
${ }^{16}$ See, for example, Canavan and Tommasi (1997), Herrendorf (1999), Keefer and Stasavage (2003), and Bearce and Hallerberg (2011). Carmignani, et al (2008) present a dissenting view.
} 
volatility (Andrews and Rees, 2009), and broader access to financing allows firms to better manage macroeconomic volatility (Cavallo et al., 2010). In this context, higher government capacities play an important role as they can provide deeper financial markets: Becerra, et al (2012), building from insights in Haber, et al (2008), show that financial development is higher in countries with enhanced government capabilities as, among other channels, they tend to abuse less the financial system in order to finance government operations.

Looking at a slightly more disaggregated level, it is clear that the effects of terms of trade shocks operate differently through different sectors of the economy. Focusing at that level, there are a number of horizontal and sectorial policies that have an impact on the performance of various economic sectors, both on average and in terms of how well they respond to various shocks. For example, labor market flexibility and ease of firm entry are policy induced characteristics that can dampen the impact of negative terms of trade shocks on aggregate output (Loayza and Raddatz, 2007). Those policies, as well as other industrial, financial, and labormarket policies are also likely to demand important government and bureaucratic capabilities in order to be implemented properly. ${ }^{17}$ Scartascini and Tommasi (2010) show that higher government capabilities are positively correlated with policies that are associated with long term gains in productivity, such as less distortive tax systems and government subsidies, a larger formal sector, higher quality infrastructure, labor market flexibility, and ease of firm entry.

Governments of open countries also try to insulate their economies from the exposure to global markets volatility through membership in international trade organizations, particularly the World Trade Organization (WTO) and preferential trading arrangements (PTAs). Mansfield and Reinhardt (2008) show find that PTAs and the WTO regime significantly reduce export

\footnotetext{
${ }^{17}$ Crespi et al (2014) provide a detailed analysis of the government capabilities necessary in order to implement various productive development policies.
} 
volatility. Once again, the effective participation in such arrangements is not likely to induce large amounts of public spending, while playing such international games tends to be quite demanding in terms of having a capable bureaucracy. ${ }^{18}$

Most of the policies mentioned so far tend to operate between the external shock and the macro and micro economic consequences of the shock. After all of that is said and done, there will still be social consequences of the remaining effects of external shocks. And there, again, are various policies to deal with that. Most of them will indeed have budgetary implications, but one might speculate that more effective governments will obtain a better bang for the buck, being able to mitigate the social costs of economic volatility more effectively and more efficiently (i.e., at a lower cost). In terms of a model with aggregate and idiosyncratic shocks, a more capable government will be better able to target its social policies at those times and to those individuals that need it the most. Programs that might have such characteristics include training programs (which also facilitate sectorial adjustment), unemployment insurance, targeted social programs, as well as a number of health and education policies (which also might matter for general productivity and for better microeconomic adjustment). Dahlström et al (2013) show that high bureaucratic quality is positively associated with greater relative spending on labor programs that require discretion to be allocated properly. Cingolani et al (2013) report how bureaucratic autonomy and state capacity allow governments to advance more rapidly in achieving development policy goals in social sector areas. Scartascini et al Tommasi (2008) report that health and education spending are more effective in countries with better policymaking

\footnotetext{
${ }^{18}$ According to Lecomte (2002) and Pasadilla (2005), best practices suggest three critical elements are necessary to achieve an efficient trade policy, namely government leadership, inclusion of all actors, and institutional capacity. Institutional capacity includes, among others, the capacity to prepare technical backgrounds, research, and analysis, and the capacity to carry out negotiations.
} 
capabilities. Brambor and Lindvall (2014) present additional evidence that countries with higher capabilities are able to pursue more efficient fiscal and social protection policies.

The examples above illustrate that there are various policies that help countries to deal with external volatility but many of those that are more efficient are also quite demanding in terms of the capabilities of governments to implement them. ${ }^{19}$ Countries with low state capabilities might not be able to deliver in some of these more demanding policies, and hence might be forced to deal with increased volatility by blunt methods such as enlarging the state ex ante. On the other hand, countries with high capabilities have a wider menu of policies at their disposal, and since some good policies not necessarily require much public spending, they might be able to cope with the extra volatility induced by trade without necessarily increasing public spending much.

What specific policies each country chooses to reduce ex ante volatility and what policies each country pursues to reduce the social impact of external shocks will depend on the specific characteristics of its economic and social environment as well as on various historical, cultural, ideological, and political factors. Some countries may choose to deepen financial markets and credit availability for a more efficient and automatic adjustment of private agents; while others may prefer to concentrate their efforts on ensuring countercyclical fiscal adjustments in order to jumpstart the economy during bad times. ${ }^{20}$ In every case though, those with higher government capabilities will have access to a superior vector of policies than those with low capabilities; and

\footnotetext{
${ }^{19}$ The evidence is not restricted to the cross-country comparison. Skocpol and Finegold (1982) show that the success of different policies to counteract the great depression in the US can be explained by the capacity of government agencies in each sector

${ }^{20}$ For example, Iversen and Soskice (2014) show how different underlying electoral coalitions affect labor and compensation policies, and Knotz and Lindvall (2014) show how the type of government (coalition or single party) determines the type of unemployment benefit.
} 
the budget implications of those policies will vary. For those reasons, in what follows we focus on a reduced form exercise conditioning the budgetary response to volatility.

\section{Empirical Analysis}

\subsection{Measuring State Capacity}

Not surprisingly, the measures of state capacity found in the literature are quite varied, some of them aiming at capturing state capacity in a broad generic way, others acknowledging the existence of several aspects or dimensions, and trying to measure each of them. Among those attempting to measure bureaucratic/administrative/implementation capacity, for the purpose of this study where we need a large coverage in terms of countries and years, we rely on the indicator of quality of the bureaucracy from the International Country Risk Guide (ICRG). The variable "bureaucratic quality" (burquality) reflects the institutional strength, quality, and expertise of the bureaucratic structure. ${ }^{21}$ Countries that score high in this variable are supposed to have the ability to accumulate knowledge over time, to invest in the development of the workforce, and to pursue long-term policies. In such contexts, policy decisions accumulate over time and policymakers are able to learn from previous mistakes.

ICRG's "bureaucratic quality" has been used to measure state capacity in articles particularly interested in administrative features of the state (Cingolani et al 2013; Van de Walle, 2005; Hanson and Sigman 2013), and in studies such as this one that attempts to capture how government capabilities affect the supply or demand of certain types of policies (see for example Becerra, et al, 2012). As is the case with many survey-based variables, concerns abound

21 "High points are given to countries where the bureaucracy has the strength and expertise to govern without drastic changes in policy or interruptions in government services. In these low-risk countries, the bureaucracy tends to be somewhat autonomous from political pressure and to have an established mechanism for recruitment and training. Countries that lack the cushioning effect of a strong bureaucracy receive low points because a change in government tends to be traumatic in terms of policy formulation and day-to-day administrative functions." (ICRG, 2009) 
regarding how well they proxy reality, how stable they are, and whether they tend to conflate with the state of economy (Kurtz and Schrank, 2007 -KZ-).

In order to reduce potential concerns, we have done several tests (which are very similar to $\mathrm{KZ}$ approach) -details are presented in the online appendix (section 1). First, we have checked if this indicator correlates well with other variables that try to proxy similar processes and more objective indicators. This indicator correlates well (around 0.6) with Evans and Rauch (1999) measure of bureaucratic quality. Additionally, this indicator of bureaucratic quality also correlates well with other dimensions of state capabilities that have been shown to relate to higher quality of policymaking in smaller country samples (within Latin America). ${ }^{22}$ Second, we examine the stability of the measure across time. Given that the quality of the bureaucracy depends on the accumulation of investments, it should change only gradually. Otherwise, the measure may be picking up either cyclical sentiment (such as economic or political fluctuations), or de jure changes (such as the approval of a reform law). The measure is highly stable over time: the regression coefficient of the lagged dependent variable is 0.85 (results in Table 1.1 in the online appendix). Finally, in order to examine whether the measure is correlated to structural or cyclical factors, we run a set of regressions of the measure on (the log of) GDPpc, GDPpc growth, a proxy for the size of the country such as (the log of) population, and education. We expect, as $\mathrm{KZ}$ did, a positive correlation of bureaucratic quality with the level of development and the level of education of the adult population. Our dependent variable should not be correlated to short-term fluctuations; therefore, we expect the coefficient for growth to be not

\footnotetext{
${ }^{22}$ See, for instance, Scartascini and Tommasi (2010), Scartascini, Stein, and Tommasi (2013), and Franco Chuaire and Scartascini (2014).
} 
significant. Empirical results for several cross-sections (each one for a different 5-year period)

and a panel, as presented in the online appendix, confirm our priors. ${ }^{23}$

\subsection{The Empirical Specification}

As stated earlier, for concreteness and easiness of the comparison, we take Rodrik's empirical framework as the baseline, and we evaluate the hypotheses of whether the connection between openness and public spending is conditional on the level of government capabilities. While governments with low bureaucratic capacities may have to deal with the effects of globalization in rudimentary ways, governments with higher capabilities may be able to access a set of policies that reduce the size of external shocks and ameliorate their consequences with a relatively low effect on public expenditures. ${ }^{24}$

The basic model we test is presented in equation (1), which includes an additional term, enclosed in brackets, to Rodrik's (1998) baseline regression:

$$
\log \left(g_{j}\right)=\beta_{0}+\beta_{1} \text { open }_{j}+\left[\beta_{2} \text { burquality }_{j}+\beta_{3}\left(\text { open }_{j} \times \text { burquality }_{j}\right)\right]+\gamma \boldsymbol{X}_{j}+\varepsilon_{j}
$$

where $g_{j}$ denotes general government final consumption expenditure as a share of GDP for country $j$ and averaged over the period $2000-2005 .^{25}$ The second main variable of interest is

\footnotetext{
${ }^{23}$ Of course, in spite of the previous tests, we do not neglect that better measures (or having at least a broader set from which to choose) would be preferable. Unfortunately, "it has been pointed out the lack of comparable measures of the bureaucracy represents the main weak point in comparative public administration (Brans 2003, Lapuente 2007, Dahlström et al 2010)" Cingolani (2013, 41).

${ }^{24}$ We do not argue in this paper about the level of government expenditures, which depend upon a myriad of factors, but about the conditionality of the relationship between external risk and size of the government. In other words, we are not implying, for example, that Paraguay, which has relatively low bureaucratic quality, would necessarily have a larger public sector than Sweden, but that both countries would set up their policies differently to react to the potential negative consequences coming from unfavorable external conditions. In the margin, a country like Sweden would have a set of more efficient policies at its disposal, which would isolate the country better from shocks and at a lower cost. Still, Sweden may still have a larger government size than Paraguay because it may be able to pursue other policy objectives.

${ }^{25}$ General government final consumption expenditure includes all government expenditures for purchases of goods and services (including compensation of employees). It also includes most expenditures on national defense and
} 
open $_{j}$ which measures the degree of openness of economy $j$ using the ratio of imports plus exports to GDP, averaged over the preceding decade (1990-1999). The main data source for these variables is the World Development Indicators from the World Bank. Bureaucratic Quality (burquality), which comes from the International Country Risk Guide (ICRG), takes values between 0 (low) and 4 (high) and is averaged over the preceding decade (1990-1999). $\boldsymbol{X}_{j}$ represents a set of control variables that includes the log of per capita GDP and the log of the dependency ratio in the population and urbanization rate from the World Bank data, and dummy variables for socialist countries, OECD members, and geographical regions. ${ }^{26}$ The set of variables is later expanded in the robustness section, as we move away from Rodrik's original specifications. $^{27}$

Since we are interested in the conditional effect, we will usually concentrate the analysis on the marginal effect of openness on government size:

$$
\frac{\partial \log \left(g_{j}\right)}{\text { open }_{j}}=\beta_{1}+\beta_{3} \text { burquality }_{j}
$$

While openness proxies exposure to economic volatility, estimating the effect of having a higher exposure to external risk is more complex than looking only at openness. Equation (3) takes this into account by adding terms of trade volatility (TOTvolatility) as a proxy for external risk as done by Rodrik. Once more, the term in brackets reflects an addition made in this paper.

security, but excludes government military expenditures that are part of government capital formation (WDI). Using long-term averages reduces the concerns from picking up short-term fluctuations. While we have run the regressions in a recent sample, which was chosen according to data availability, we have also performed the same exercises in several other periods and in Rodrik's sample period. These results are presented in the online appendix. Consequently, our results do not depend on the period chosen for the analysis

${ }^{26}$ All the control variables except for the dummy variables are also averaged over the 1990-1999 period. See all summary statistics in Table A1 of the Appendix.

${ }^{27}$ In all the exercises reported in the paper, we use the broadest possible sample of countries (broad sample). In the online appendix, we include the results for a narrower sample, which includes those countries that are thought to belong to Rodrik's sample according to the data sources used in his baseline empirical analysis. 


$$
\begin{aligned}
& \log \left(g_{j}\right)=\beta_{0}+\beta_{1} \text { open }_{j}+\beta_{2} \text { TOTvolatility }_{j}+\beta_{3}\left(\text { open }_{j} \times \text { TOTvolatility }_{j}\right)+ \\
& {\left[\beta_{4} \text { burquality }_{j}+\beta_{5}\left(\text { open }_{j} \times \text { burquality }_{j}\right)+\beta_{6} \text { (ToTvolatility }_{j} \times\right.} \\
& \text { burquality } \left.\left.\left._{j}\right)+\beta_{7} \text { open }_{j} \times \text { TOTvolatility }_{j} \times \text { burquality }_{j}\right)\right]+\gamma \boldsymbol{X}_{j}+\varepsilon_{j}
\end{aligned}
$$

TOTvolatility $y_{j}$ is defined as the standard deviation of the log-differences in terms of trade for the period 1980-1999 and all the other variables have the same meaning as in the baseline regression. The interaction term between openness and terms of trade volatility aims to capture that external risk depends not only on how open each country is but also on how exposed it is (because of that level of openness and the characteristics of its economy) vis-à-vis the rest of the world. ${ }^{28}$

In addition to the cross-sectional analysis, we also work with a panel for the period 19802004. Following the literature, we divide this period into five sub-periods by collapsing the data into five-year averages, which allows us to remove business cycle variations. ${ }^{29}$ The panel regressions are run using both fixed effects and random effects, and including and excluding period dummies and additional controls. The core results are presented in the paper and the rest in the online appendix. The complete model specification is given by:

$$
\begin{aligned}
& \log \left(g_{j t}\right)=\alpha_{0}+\alpha_{1} \text { open }_{j t-1}+\left[\alpha_{2} \text { (burquality }_{j t-1}\right)+ \\
& \left.\left.+\alpha_{3} \text { open }_{j t-1} \times \text { burquality }_{j t-1}\right)\right]+\delta \boldsymbol{X}_{j \bar{t}}+\vartheta_{j}+\eta_{t}+\epsilon_{j t} \\
& \log \left(g_{j t}\right)=\alpha_{0}+\alpha_{1} \text { open }_{j t-1}+\alpha_{2}\left(\text { TOTvolatility }_{j t-1}\right)+
\end{aligned}
$$

\footnotetext{
${ }^{28}$ Note that openness is not in logarithms in this version of the benchmark, to allow for the inclusion of terms of trade volatility in levels both individually and in interacted with openness (Rodrik, 1998).

${ }^{29}$ See for example Rodrik (1998), Andrews and Rees (2009), and Becerra, Cavallo and Scartascini (2012).
} 
$+\alpha_{3}$ open $_{j t-1} \times$ TOTvolatility $\left._{j t-1}\right)+\left[\alpha_{4}\left(\right.\right.$ burquality $\left._{j t-1}\right)+$

$+\alpha_{5}\left(\right.$ open $_{j t-1} \times$ burquality $\left._{j t-1}\right)+\alpha_{6}\left(\right.$ TOTvolatility $_{j} \times$ burquality $\left._{j t-1}\right)+\alpha_{7}\left(\right.$ open $_{j t-1} \times$

TOTvolatility $_{j} \times$ burquality $\left.\left._{j t-1}\right)\right]+\delta \boldsymbol{X}_{j \bar{t}}+\vartheta_{j}+\eta_{t}+\epsilon_{j t}$

The dependent variable is again the share of government consumption in GDP for country $j$ averaged over the five-year period $t\left(g_{j t}\right)$. The regressors include a lagged measure of openness to international trade $\left(\right.$ open $\left._{j t-1}\right)$ and bureaucratic quality (bureaucracy $\left.y_{j t-1}\right)$, and the same controls as in the cross-country analysis. $\boldsymbol{X}_{\boldsymbol{j} \boldsymbol{i}}$ includes the regressors at the beginning of each period such as the log of real per capita GDP, log urbanization rate, and log dependency ratio, and dummy variables for OECD members and socialist countries. $\vartheta_{j}$ and $\eta_{t}$ denote country-specific and time-specific effects, respectively. We run these exercises using both fixed and random effects and perform the respective Hausman tests to choose the appropriate model (the fixed effects model figures are included in the text and the random effects models in the online appendix).

\subsection{Regression Results}

Table 1 presents the first set of results. The dependent variable is the log average government consumption for the period 2000-2005. The independent variables use the averages over the previous decade. ${ }^{30}$ In column 1 we replicate Rodrik's baseline cross-country regression for openness and we include the new terms in column 2. It is important to note, that the results in column 1 are not as significant in this period as they were in the original sample period studied by Rodrik (which in part may be explained by higher sophistication in the part of countries in the way they react to external risks - more efficient ways of coping with external risk have become

\footnotetext{
${ }^{30}$ Denoted as $t-1$ in the tables.
} 
available over time for those with high capacities). As it can be observed in column 2, the coefficients are statistically significant and they go in the direction that we expected. Absent any bureaucratic capacities, openness has a large, positive and significant effect on government consumption-similar in size to Rodrik's findings. A 10 percentage points larger share of total trade in GDP is associated with a 5 percent larger share of government consumption in GDP. Countries with higher bureaucratic quality do also seem to present higher expenditures, which is in line with the literature (higher abilities allow countries to pursue other policy objectives that weaker countries cannot pursue).

However, countries differ in their ability to pursue policies and how to respond to higher external risk, which is picked up in a negative (and significant) coefficient for the interaction term between openness and bureaucratic quality. That is, openness has a positive effect, but this effect tends to be attenuated by higher levels of bureaucratic capacities. Taken together, in terms of its economic relevance, while increasing the level of openness in one standard deviation would have no effect on the size of the government for a country like Sweden, it would have a positive effect for a country like Paraguay (trade related expenditures would increase by $12 \%$ ), and even a larger effect for a country like Sierra Leone (23\%). 


\section{Table 1. The Effects of Openness and External Risk on Government Size,}

\section{Accounting for Government Capabilities: Cross-Section}

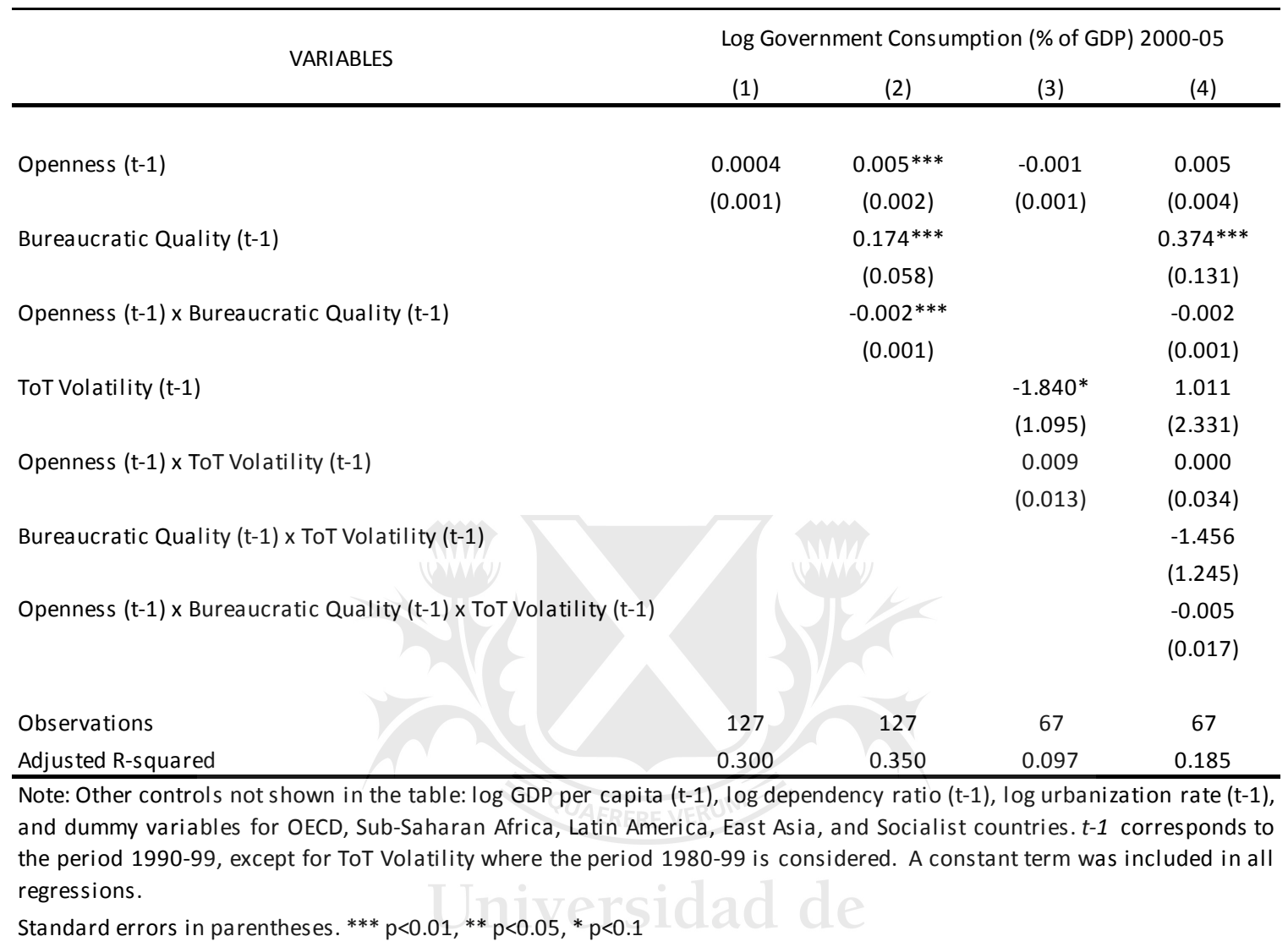

The marginal effect of openness on government consumption at different levels of bureaucratic capacity is represented in Figure 1; the marginal effect of openness on government size is positive for low levels of bureaucratic quality (mimicking Rodrik's compensation hypotheses results) but it decreases as these capacities increase to the point of becoming insignificant. ${ }^{31}$ As can be observed in the summary statistics, this effect takes place around the mean of the distribution. In other words, openness has a positive effect on government

\footnotetext{
${ }^{31}$ The graphical representation of the results is important because in a model with interactive terms, the significance of the constituent terms of an interaction cannot be fully assessed independently from the interaction term (Brambor, Clark, and Golder 2005), and the results are not independent of the underlying distribution of the conditional variable.
} 
consumption for those countries with a bureaucratic quality score approximately below 2.2 out of 4 points (such as Sierra Leone and Paraguay) and no effect for countries on the higher end of the distribution (such as Sweden, Canada and Germany). ${ }^{32}$

\section{Figure 1. Marginal Effect of Trade Openness on Government Consumption along Bureaucratic Quality: Cross Section}

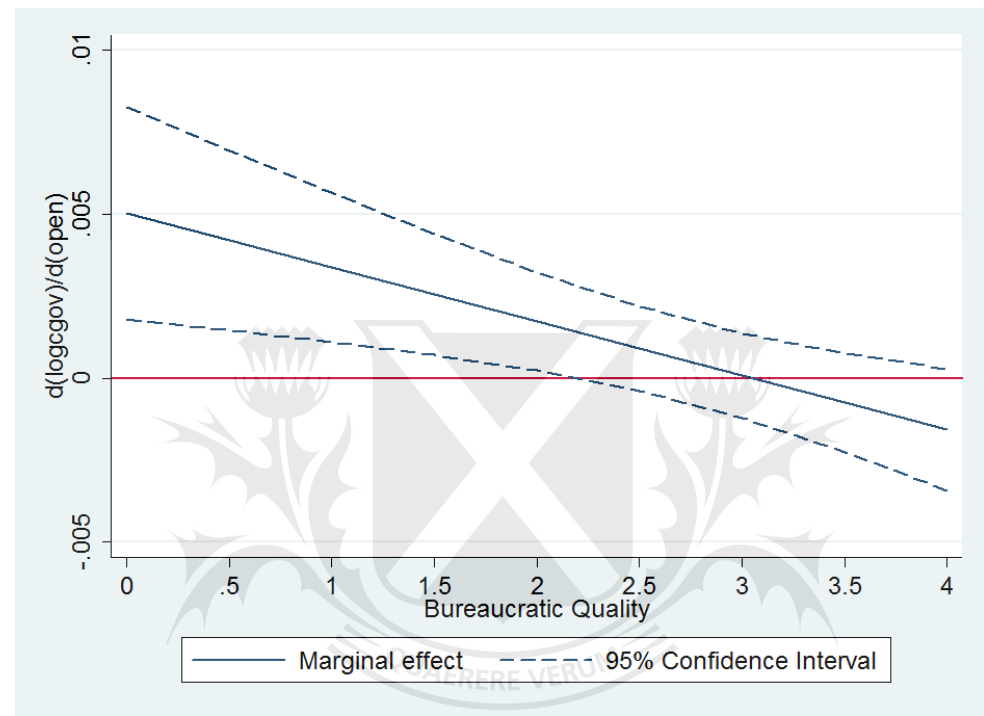

Note: The figure corresponds to the regression in column 2 of Table 1.

We present even more intuitive results in the online appendix (section 4), where, using cluster analysis, we split the sample among those countries with high and low bureaucratic quality. ${ }^{33}$ For splitting the sample we use cluster analysis. The results go in the same direction than those presented here. While we find no significant relationship between trade and size of the government for the set of countries with high capabilities (about 50 countries), we find a positive

\footnotetext{
${ }^{32}$ We do not believe this result is driven by multicolinearity because of the significant simple correlation between size and openness and the absence of outliers driving the results (the same results are obtained in different samples as described later). See Chatelain and Ralf (2012).

${ }^{33}$ For splitting the sample according to the bureaucratic quality index, we use k-means and the L1-norm. k-means is the better known and more widespread clustering procedure that yields a partition of the space and it generates uniformly consistent estimations of the underlying density.
} 
and statistically significant coefficient for those countries that clustered among the weakest (more than 70). This result holds for different samples.

Column 3 (Table 1) incorporates the notion of external risk by adding terms of trade volatility and the interaction with openness. Similarly to Rodrik's original results, the interaction term between openness and volatility is positive which implies that the key aspect is not necessarily the degree of openness of the economy but the actual increase of external risk measured by the combination of openness and TOT volatility. Once more, the results are not as significant in this period as they were in the original sample period studied by Rodrik. However, the effect of external risk on government consumption is decreasing in bureaucratic quality (the significantly smaller sample size may be affecting the significance of the coefficients) -we find more significant results in the panel and IV analyses. Figure 2 summarizes the marginal effect of openness at different levels of bureaucratic quality taking TOT volatility at its $50^{\text {th }}$ percentile. Corresponding figures at other values of the distribution are very similar. 
Figure 2. Marginal Effect of Trade Openness on Government Consumption along Bureaucratic Quality (taking ToT Volatility at $\mathbf{5 0}^{\text {th }}$ Percentile)

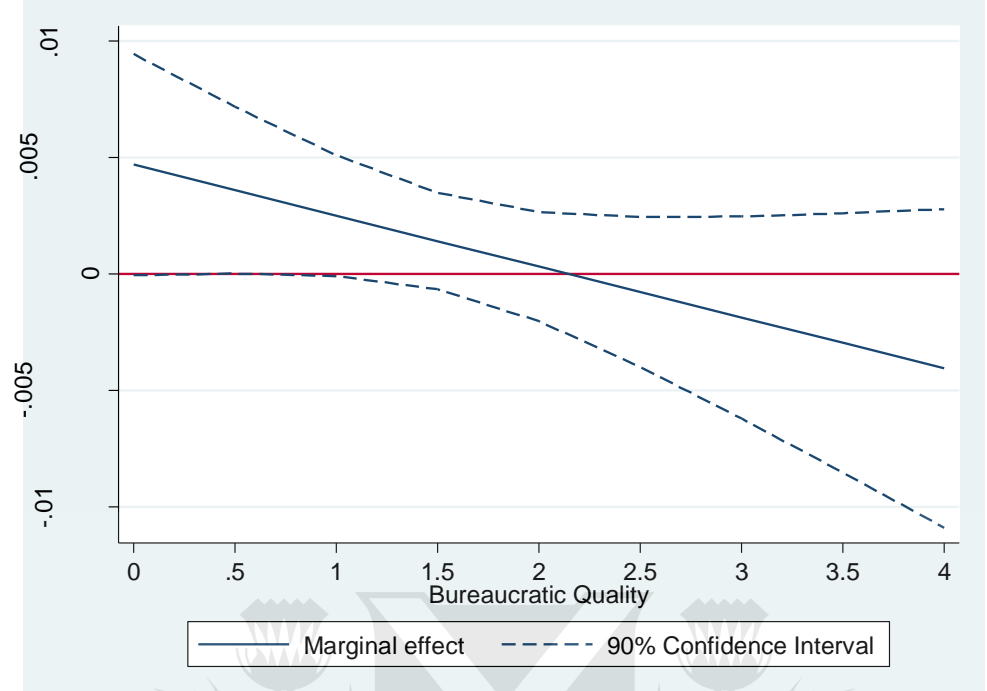

Note: The figure corresponds to the regression in column 4 of Table 1.

Table 2 presents the results for the panel data. Using this data allows us to capture also the dynamics of change and controlling for unobservables. A priori, a random effects estimation would seem to be preferred as bureaucratic quality should not vary much and it would provide more degrees of freedom in the estimation. Still, a fixed effect models would reduce the potential for biased estimations. We have performed both fixed effects and random effects estimations, and the results are qualitatively equivalent. We report in Figure 3 the results from the fixed effect models, which includes the full set of time and country fixed effects, and the corresponding random effect figures are included in the online appendix (section 5). The left panel of Figure 3 corresponds to the results in column 1 and the right panel to those in column 2 (once again, evaluated at TOT's $50^{\text {th }}$ percentile). Similar to the cross-section, the marginal effect of openness on the share of government consumption in GDP is decreasing with bureaucratic quality and positive and significant for countries with weak bureaucracies. Hence, past exposure to external risk is a statistically significant determinant of government size conditional on state capacity, and 
this result is not purely cross-sectional; it holds within countries even when year and country fixed effects are included as well.

\section{Table 2. The Effects of Openness and External Risk on Government Size, Accounting for Government Capabilities: Panel Data}

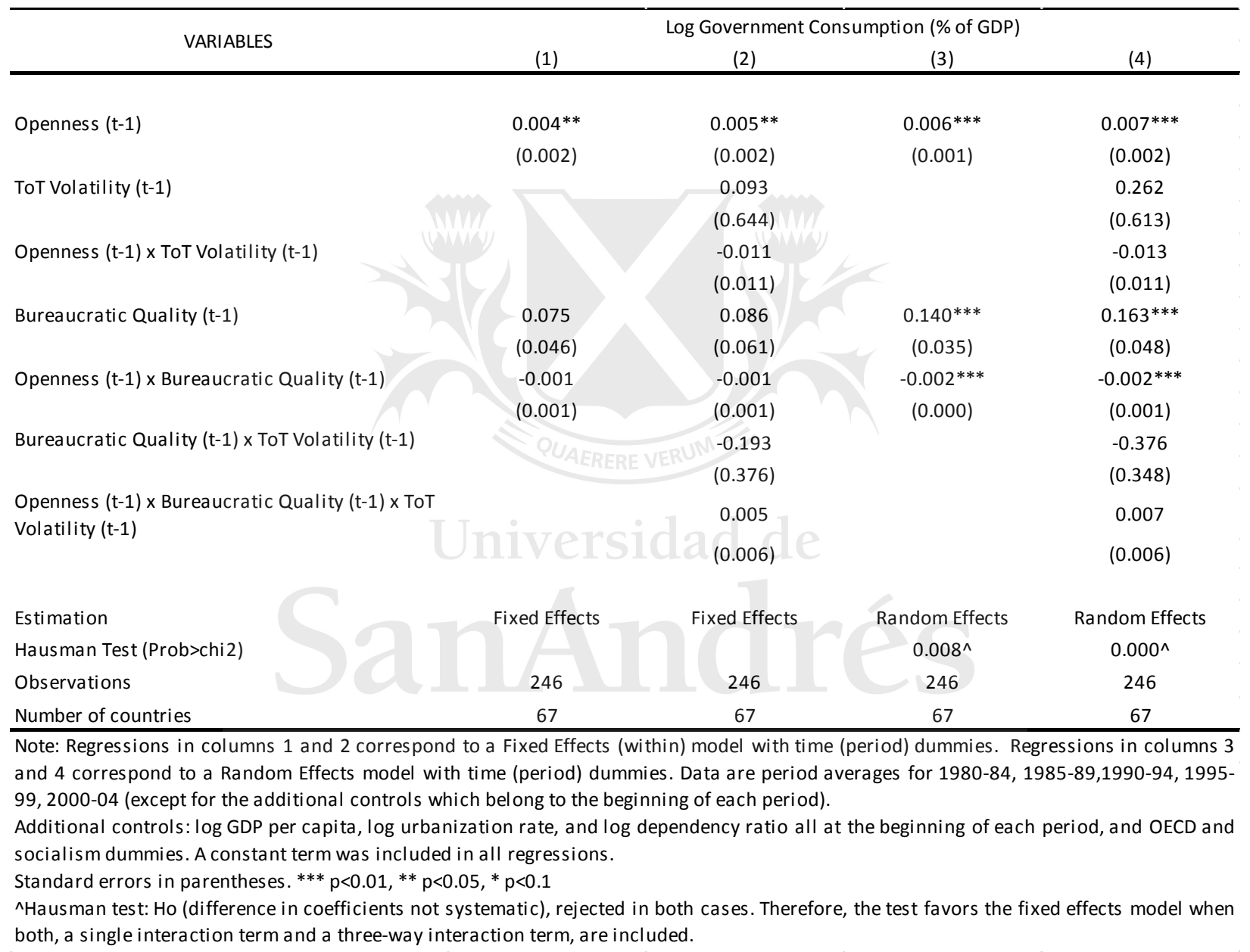


Figure 3. Marginal Effect of Trade Openness on Government Consumption along Bureaucratic Quality: Panel Data

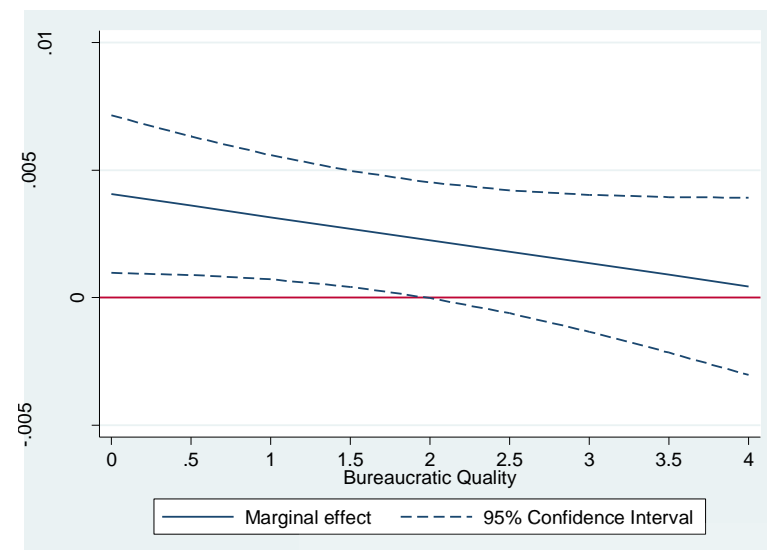

a. Column 1 of Table 2.

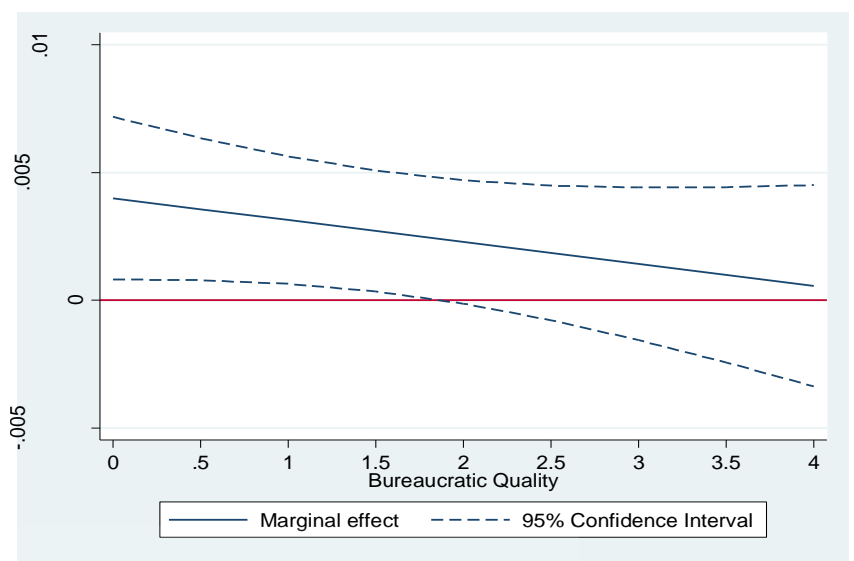

b. Column 2 of Table 2 (TOT Volatility $50^{\text {th }}$ p.)

Are these effects stable over time? In order to check this we run a series of cross-sections evaluating the dependent variable in the five-year periods 90-94, 95-99, and 00-04 (results are presented in the online appendix -section 6). While we obtain the same qualitative results, the intercept and slope of the conditional relationship change over time, particularly between the first two sub-periods. In the 1995-99 period, the intercept (the coefficient of openness) is smaller and the slope is shallower. This evidence may be consistent with a pattern in which there is learning and policy diffusion, which allows more countries to pursue more efficient policies. This evidence may serve as a first indication of why the statistical and economic significance of Rodrik's results has fallen over time.

\subsection{Robustness Checks}

So far we have evaluated our hypothesis in the context of Rodrik's framework in order to facilitate comparisons. However, as surveyed in Section 3, Rodrik's results have been widely revisited and concerns have been raised about the omission of relevant variables that may be affecting the discussed relationship between openness and government size such as population 
size and democratic institutions. Moreover, the broad literature on the size of the government has confirmed some effects of constitutional rules on the size of government: presidential systems have been found to lead to smaller governments while proportional representation systems (compared to majoritarian systems) lead to larger governments. ${ }^{34}$ As a first robustness check we test our hypothesis in the context of an expanded set of controls to avoid omitted variable biases.

Furthermore, the inclusion of our variable of interest, namely bureaucratic quality, may raise a potential concern regarding causation and biases due to endogeneity. Could causality be running from government size to quality of the bureaucracy? Even though it is not immediately clear why this would be generating the previous set of results, in the second part of the section we use an instrumental variables approach in order to reduce this concern.

In order to address the possibility that our measure of bureaucratic quality may be picking up something else, in the last part of the section we run some placebo analysis using other potential explanatory variables of the differential responses across countries. We find that none of them produce the same conditional effects.

\subsubsection{Expanded Controls}

Table 3 presents the same exercises as in Table 1 using a set of expanded controls that includes population size (log population), the freedom house score (GASTIL) on political rights and civil liberties, average effective tariffs (tariff rate) given by the percentage of total import duties as a share of the total value of imports, a dummy variable equal to 1 when the form of government is presidential (pres) and 0 otherwise, and a dummy variable that is equal to 1 when the electoral rule for the lower or only house is majoritarian $(\mathrm{maj}) .{ }^{35}$ As can be observed in the table, including

\footnotetext{
${ }^{34}$ See Persson and Tabellini (2003).

${ }^{35}$ We also run the same exercises including a dummy variable for countries with a federal structure. However, this variable presents several problems such as the reduction of our sample size. After including it, the marginal effect of
} 
additional controls does not change the direction of the results. Again, the marginal effect of openness (or exposure to external risk) on government consumption seems to be lower for countries with higher bureaucratic capacities. Figure 4 presents this information graphically showing that the positive effect of openness seems to be relevant only for low levels of capacities (when the quality of bureaucracy is approximately below 2 out of 4 points). Similar results are found when we look at the three-way interaction term even though these results are less precise because of sample issues (including additional controls reduces the sample size substantially).

Table 3. Accounting for Government Capabilities and Terms of Trade Volatility: Expanded Set of Controls

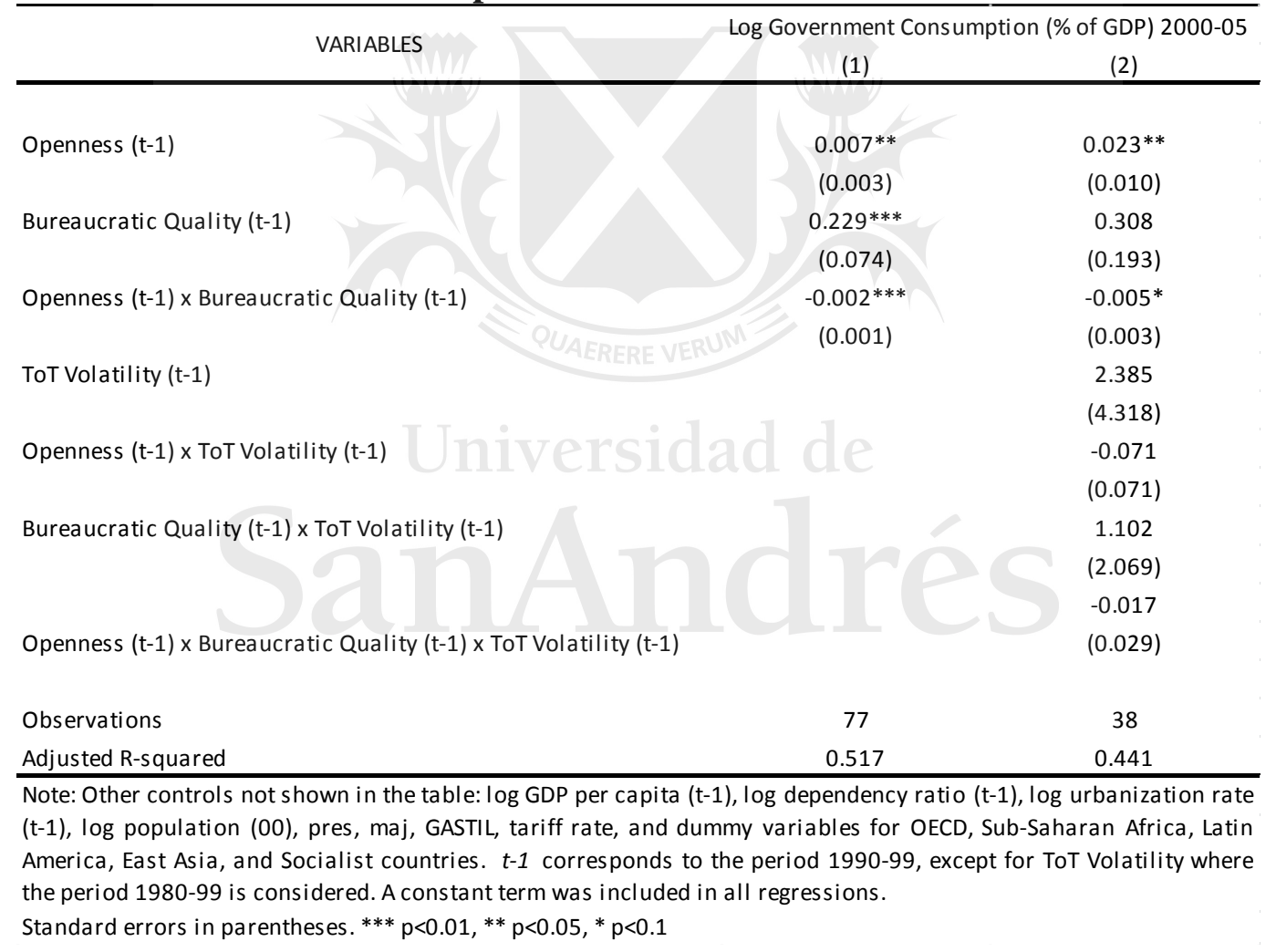

openness on government size remains decreasing with bureaucratic quality and positive for low scores of the latter. However, the results are not as significant as before. 


\section{Figure 4. Marginal Effect of Trade Openness on Government Consumption along Bureaucratic Quality: Expanded Set of Controls}

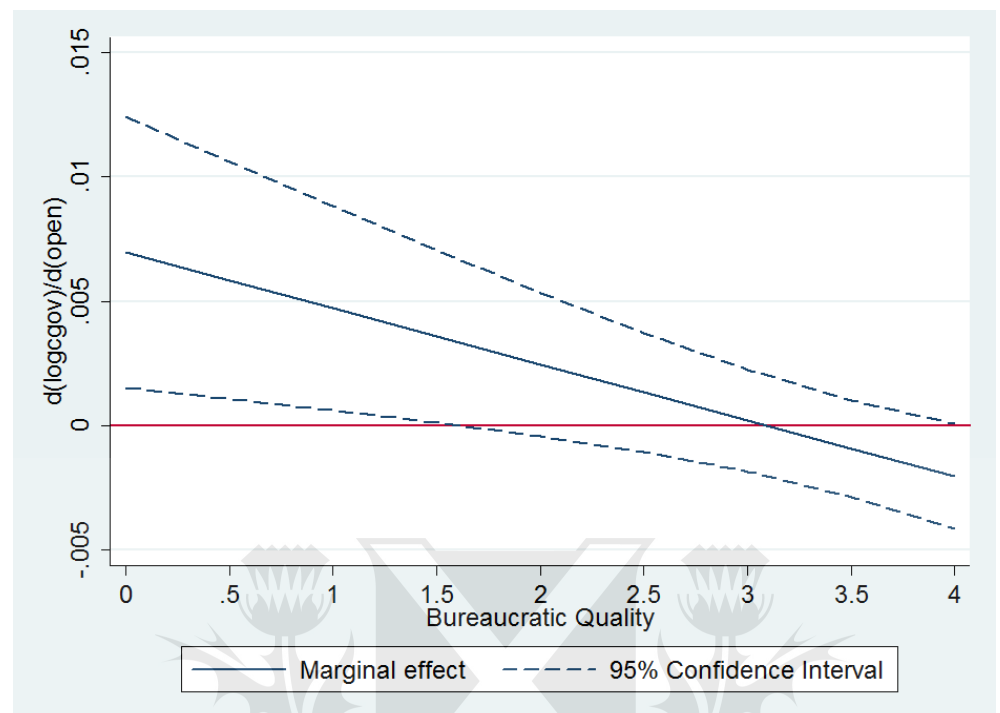

Note: The figure corresponds to the regression in column 1 of Table 3.

\subsubsection{Instrumenting for Bureaucratic Quality}

To address potential reverse causality problems between bureaucratic quality and size of the government, we use an instrumental variables approach. Finding good instruments for bureaucratic quality is not an easy task.

Given that bureaucratic capacity is not a feature that can be built overnight but it depends on a series of investments done by the polity overtime on a third-party that would help to enforce commitments and long-standing rules, it seems natural to use variables that proxy for the stability of the political system and democratic heritage. ${ }^{36} \mathrm{~A}$ first set of potential instrument variables, then, includes age of democracy (age), the date of first democratic elections ( $m e$ ), and

\footnotetext{
${ }^{36}$ See for instance Besley and Persson (2009) and Enriquez and Centeno (2012).
} 
the date of first democratic constitutions $(m c)$, and its squares. " $m e$ ", a variable that proxies working democracies, captures well the ability of the polity to invest on the development of institutions over time (Rockey 2012). A measure of political stability could be another proxy for this ability to invest in the institutionalization of the bureaucracy that should not be related to the size of the government. ${ }^{38}$ Additionally, we use, as many before us have done, the measure of European settler mortality during colonization by Acemoglu, Johnson, and Robinson (2001), as a source of exogenous variation in state capacity. ${ }^{39}$

Another potential instrument comes from Cruz and Keefer (2013). According to the authors, when politicians are bound together by the existence of programmatic parties, they are more likely to develop organizational arrangements that limit free-riding and promote collective action, such as those reforms that promote a well-functioning public administration. ${ }^{40}$

Finally, we also use several variables from the Comparative Constitutions Project, CCP (Elkins, Ginsburg, and Melton, 2008) that might explain bureaucratic quality while meeting the exclusion restriction. First, we use the variable civil to measure whether the constitution of a given country includes provisions for the meritocratic recruitment of civil servants. We would expect these provisions to be positively correlated to bureaucratic quality and to affect government consumption only through its effect on the instrumented variable. Second, countries in which politicians invest in the development of the bureaucracy tend to be countries in which there are similar investments made in other third party enforcement mechanisms. Consequently,

\footnotetext{
${ }^{37}$ Including age 2 as well as age provides a parsimonious way to capture any non-linearities in the history of constitutional fashion (Rockey, 2012: p. 314).

${ }_{38}^{38}$ See Besley and Persson (2009).

${ }^{39}$ The authors argue that colonization strategies, which relied on different types of institutions, were influenced by the feasibility of settlements. In places where disease was more likely, European powers set up more extractive states that favored a weaker system of checks and balances and protection for private property.

${ }^{40} \mathrm{We}$ create a variable that measures the share of parties (from the largest three government parties and the largest opposition party) that is identified as having right, left, or center orientation (rlc_avg) using data from the Database of Political Institutions, DPI (Beck et al. 2001).
} 
those countries that vest legislatures with oversight powers and insure the judiciary from manipulation from the executive tend also to invest in stronger bureaucracies. We use the variable intexec to measure whether the legislature has the power to interpellate members of the executive or if the executive must report to the legislature at regular intervals, ${ }^{41}$ and the variable jundind reports whether the constitution contains an explicit declaration regarding the independence of the central judicial organs (Elkins, Ginsburg, and Melton, 2008).

According to the empirical results, those that perform better in the first stage are $m e$, which records the number of months since the inception of democracy as measured by the date of first democratic elections, and civil, from the CCP, which measures the existence of meritocratic conditions for the recruitment of civil workers. ${ }^{42}$ We run the regressions using Fuller's modified limited-information maximum likelihood estimator, which performs better than 2SLS in the presence of weak instruments and has good finite sample properties (Rockey 2012). Table 4 presents the second stage results. ${ }^{43}$ Again the interaction term is negative and, as Figure A1 in the appendix shows, the marginal effect of openness on government size turns out to be positive and significant for low levels of quality of policymaking but decreasing as the latter increases. The results do not change across specifications. Results and first-stage tables for the rest of the instruments are presented in the online appendix.

\footnotetext{
${ }^{41}$ In the CCP (Elkin, Ginsburg, and Melton, 2008) Intexec is equal to 1 if the legislature can call the executive to report as it sees fit; 2 if the executive must report to legislature at regular intervals; 3 if both; and 4 if neither apply. We have built a variable that ranges from 0 to 2 , where 2 indicates that both conditions apply, 1 that only one applies, and 0 that neither is stipulated in the constitution.

${ }^{42}$ Note that our sample size decreases significantly when civil is used as the instrumental variable.

${ }^{43}$ See Table A2 in the Appendix for the first-stage results. In the online appendix, we also present the first and second stage results when the other instruments are used.
} 
Table 4. Instrumental Variables (Second Stage): Fuller Estimator

\begin{tabular}{|c|c|c|c|c|c|c|}
\hline \multirow{2}{*}{ VARIABLES } & \multicolumn{6}{|c|}{ Log Government Consumption (\% of GDP) 2000-05 } \\
\hline & $(1)$ & $(2)$ & (3) & (4) & (5) & $(6)$ \\
\hline \multirow[t]{2}{*}{ Openness (t-1) } & $0.007^{*}$ & $0.009 * * *$ & $0.008^{* * *}$ & $0.007^{*}$ & $0.011^{* *}$ & $0.019 * * *$ \\
\hline & $(0.004)$ & $(0.003)$ & $(0.003)$ & $(0.004)$ & $(0.005)$ & $(0.004)$ \\
\hline \multirow[t]{2}{*}{ Bureaucratic Quality (t-1) } & 0.128 & $0.255^{* *}$ & 0.119 & 0.091 & 0.179 & $0.314^{* * *}$ \\
\hline & $(0.110)$ & $(0.102)$ & $(0.111)$ & $(0.112)$ & $(0.110)$ & $(0.073)$ \\
\hline \multirow[t]{2}{*}{ Openness (t-1) x Bureaucratic Quality (t-1) } & $-0.002 * * *$ & $-0.003^{* * *}$ & $-0.002 * * *$ & $-0.002 *$ & $-0.003^{* * *}$ & $-0.005^{* * *}$ \\
\hline & $(0.001)$ & $(0.001)$ & $(0.001)$ & $(0.001)$ & $(0.001)$ & $(0.001)$ \\
\hline Expanded Controls & No & No & No & Yes & Yes & Yes \\
\hline Excluded Instruments & me, me*openness & $\begin{array}{c}\text { me, me*openness, } \\
\mathrm{me}^{\wedge} 2, \mathrm{me}^{\wedge} 2{ }^{*} \text { openness }\end{array}$ & civil , civil*openness & me, me*openness & $\begin{array}{c}\text { me, me*openness, } \\
m e^{\wedge} 2, m^{\wedge} 2^{*} \text { openness }\end{array}$ & civil, civil*openness \\
\hline Observations & 86 & 86 & 52 & 77 & 77 & 34 \\
\hline Adjusted R-squared & 0.472 & 0.510 & 0.304 & 0.476 & 0.450 & 0.753 \\
\hline
\end{tabular}

\subsubsection{Placebo Analysis}

In spite of the checks we have performed on the measure of bureaucratic quality, and the robustness exercises just presented, it could still be possible that our measure could be picking up something else. That is, that our measure is proxying some other underlying process which are more relevant for explaining the process of compensation. One option could be that somehow our variable is proxying inequality (Gini coefficient), or fractionalization in society (ethnolinguistic fractionalization index). In the first case, the underlying logic would be that those countries with higher inequality are the ones that decide to compensate the most; alternatively, those which are more fractionalized are the ones that would tend to isolate the different groups from external shocks to avoid conflicts. Other options could be that the level of democracy (Gastil) or institutional constraints (Checks) matter. We bring these hypotheses to the data but we find that none of them produce the same conditional effects. The coefficient of the interaction between openness and the placebo variable turns out to be not significant in each and every one of the regressions (results in the online appendix.) 


\section{Concluding Remarks}

Countries with different levels of state capacity have access to different sets of policies. This fact has long been recognized in the comparative politics literature, ${ }^{44}$ and has been more recently discovered in the development profession as a requisite for policy advice ("one size does not fit all"). ${ }^{45}$ In this paper we make explicit the argument that countries with higher capacities would choose those policies that are more efficient for dealing with their policy objectives. ${ }^{46} \mathrm{We}$ apply this framework to a well-known hypothesis in international political economy that argues that government spending acts as a cushion against external risk volatility for countries with high exposures to international trade. We argue that the ability of different countries to properly deal with various risks and uncertainties introduced by the volatility of international markets is conditioned by their governmental capabilities. Some countries might develop more effective ways to cope with economic volatility, ways that do not necessarily require important increases in public spending. More specifically, we find that the marginal increase of government size because of higher exposure to external risk takes place only in those countries with low bureaucratic capabilities and it tends to disappear for those countries that have a stronger bureaucracy. This result holds in the cross-section, panel, and instrumental variables regressions, and across different samples. The result is also robust to different specifications. ${ }^{47}$

This finding constitutes another step in an agenda attempting to build bridges between the study of institutions and policymaking in contexts of both high and low institutionalization, as well as contexts of high and low government capabilities. The results suggest various areas in

\footnotetext{
${ }^{44}$ Skocpol and Amenta (1986), Evans et al (1985), Haggard and Kaufman (1992).

${ }^{45}$ See for instance Pritchett et al (2010).

${ }^{46}$ This does not mean that policy objectives would be common across countries with similar capacities, or that they would make the same distributional choices.

${ }^{47}$ This result does not imply that these countries would have a smaller government overall, but that their larger size would not be a consequence of exposure to external risk but to a myriad of other factors (history, culture, ideology, political institutions).
} 
which further research seems warranted. It would be desirable to develop a broader class of theoretical models that incorporate the relevance of government (and bureaucratic) capabilities for the policy choice set in the context of external risk.

On the empirical side, the exercise we have performed in this paper is only one out of many. As government capabilities affect the vector of policies countries are able to choose from, its relevance goes beyond the specific confines of the relationship between openness and size. Additionally, the measure of capabilities we have used in this paper were those that we could construct from readily available data, but there is ample room to improve upon our definitions and to develop richer, broader, and more accurate measures. Those measures may also help to run models that help to understand how capabilities relate to specific policy choices within the vector of policies discussed here - that is, not only that some countries choose superior vectors of policies but also to identify the composition within those vectors.

We also believe that deeper studies of experiences at the country level should be developed. The study of specific dynamics of specific policies in specific countries seems to be a prerequisite for understanding the mechanisms through which government capabilities affect the design and implementation of public policies, and hence social welfare.

The findings in the paper offer additional insights into the relevance of increasing government capabilities. Such governmental capabilities do not evolve overnight, and they cannot be constructed by fiat by writing an institutional reform law. They are the outcome of actions of key political players over time, in the context of country-specific political equilibria. Still, there are plenty of investments that can be pursued that may lead to better-functioning bureaucracies and more efficient policies. 


\section{References}

Acemoglu, D., Johnson, S., and Robinson, J. (2001). The Colonial Origins of Comparative Development: An Empirical Investigation. American Economic Review 91(5), 13691401.

Adserà, A., and Boix, C. (2002). Trade, Democracy, and the Size of the Public Sector: The Political Underpinnings of Openness. International Organization 56, 229-262.

Alesina, A., and Wacziarg, R. (1998). Openness, Country Size and Government. Journal of Public Economics 69, 305-321.

Andrews, D., and Rees, D. (2009). Macroeconomic Volatility and Terms of Trade Shocks. Working Paper 2009-05. Sydney, Australia: Reserve Bank of Australia.

Avelino, G., Brown, D.S., and Hunter, W. (2005). The Effects of Capital Mobility, Trade Openness, and Democracy on Social Spending in Latin America, 1980-1999. American Journal of Political Science 49, 625-641.

Avelino, G., Brown, D.S., and Hunter, W. (2001). Globalization, Democracy, and Social Spending in Latin America, 1980-1997. Mimeographed document. Available at: http://www.colorado.edu/ibs/pec/gadconf/papers/avelino_brown_hunter.pdf

Baker, A. (2008). Public Opinion and the Compensation Hypothesis. Boulder, United States: University of Colorado at Boulder, Department of Political Science. Available at: https://ncgg.princeton.edu/IPES/2008/papers/F13_paper3.pdf

Barro, R., and Lee, J-W. (2010). A New Data Set of Educational Attainment in the World, 19502010. Journal of Development Economics 104, 184-198.

Bates, R.H., Brock, P., and Tiefenthaler, J. (1991). Risk and Trade Regimes: Another Exploration. International Organization 45 1-18. 
Bearce, D., and Hallerberg, M. 2011. Democracy and de Facto Exchange Rate Regimes. Economics \& Politics 23(2), 172-194.

Becerra, O., Cavallo, E., and Scartascini, C. (2012). The Politics of Financial Development: The Role of Interest Groups and Government Capabilities. Journal of Banking \& Finance 36, 626-643

Beck, T., Clarke, G., Groff, A., Keefer, P., and Walsh, P. (2001) (DPI) New Tools in Comparative Political Economy: The Database of Political Institutions. World Bank Economic Review 15(1), 165-176.

Besley, T., and Persson, T. (2009). The Origins of State Capacity: Property Rights, Taxation, and Politics. American Economic Review 99(4), 1218-1244.

Blume, L., Müller, J., and Voigt, S. (2009). The Economic Effects of Direct Democracy: A First Global Assessment. Public Choice 140(3-4), 431-461.

Brambor, T., Clark, W., and Golder, M. (2005). Understanding Interaction Models: Improving Empirical Analyses. Political Analysis 14(1), 63-82.

Brambor, T., and Lindvall, J. (2014). Fiscal Capacity, Domestic Compensation, and Trade Policy: A Long Term View. Lund, Sweden: Lund University. Mimeographed document.

Brans, M. (2003). Comparative public administration: from general theory to general frameworks. Handbook of Public Administration (pp. 424-439). London, England: Sage.

Broda, C., and Tille, C. (2003). Coping with Terms-of-Trade Shocks in Developing Countries. Current Issues in Economics and Finance 9(11). New York, United States: Federal Reserve Bank of New York. Available at: http://www.newyorkfed.org/research/current_issues/ci9-11.pdf

Burgoon, B. (2001). Globalization and Welfare Compensation: Disentangling the Ties that Bind. International Organization 55(3), 509-551 
Calderón, C., Duncan, R., and Schmidt-Hebbel, K. (2012). Do Good Institutions Promote Counter-Cyclical Macroeconomic Policies? Working Paper 118. Dallas, United States: Federal Reserve Bank of Dallas, Globalization and Monetary Policy Institute.

Cameron, D.R. (1978). The expansion of the public economy. American Political Science Review 72, 1243-1261.

Canavan, C., and Tommasi, M. (1997). On the Credibility of Alternative Exchange-Rate Regimes. Journal of Development Economics 54(1),101-22.

Carmignani, F., Colombo, E., and Tirelli, P. (2008). Exploring Different Views of Exchange Rate Regime Choice. Journal of International Money and Finance 27(7), 1177-1197.

Caruso, G., Scartascini, C., and Tommasi, M. (2013). Are We All Playing the Same Game? The Economic Effects of Constitutions Depend on the Degree of Institutionalization. Working Paper IDB-WP-237. Washington, DC, United States: Inter-American Development Bank.

Cavallo, E., Galindo, A., Izquierdo, A., Leon, J. (2010). The Role of Relative Price Volatility in the Efficiency of Investment Allocation. Working Paper IDB-WP-208. Washington, DC, United States: Inter-American Development Bank.

Céspedes, F., and Velasco, A. (2013). Was This Time Different? Fiscal Policy in Commodity Republics. NBER Working Paper 19748. Cambridge, United States: National Bureau of Economic Research.

Chatelain, J-B., and Ralf, K. (2012). Spurious Regressions and Near-Multicollinearity, with an Application to Aid, Policies and Growth. MPRA Paper 42533. Available online at http://mpra.ub.uni-muenchen.de/42533/

Cingolani, L. (2013). The State of State Capacity: A Review of Concepts, Evidence, and Measures. UNU-MERIT Working Paper 2013-053. Maastricht, The Netherlands: United 
Nations University-Maastricht Economic and Social Research Institute on Innovation and Technology.

Cingolani, L., Thomsson, K., and de Crombrugghe, D. (2013). Minding Weber More than Ever? The Impacts of State Capacity and Bureaucratic Autonomy on Development Goals. UNU-MERIT Working Paper 2013-052. Maastricht, The Netherlands: United Nations University-Maastricht Economic and Social Research Institute on Innovation and Technology.

Crespi, G., Fernandez-Arias, E., and Stein, E.. (2014). Rethinking Productive Development. Sound Policies and Institutions for Economic Transformation. New York, NY: Palgrave MacMillan.

Cruz, C., and Keefer, P. (2013). The Organization of Political Parties and the Politics of Bureaucratic Reform. Policy Research Working Paper 6686. Washington, DC, United States: World Bank.

Dahlstrom, C., Lapuente, V., and Teorell, J. (2010). Dimensions of bureaucracy: a cross-national dataset on the structure and behavior of public administration. QoG Working Paper Series, 13.

Dahlström, C., Lindvall, J., and Rothstein, B. (2013). Corruption, Bureaucratic Failure, and Social Policy Priorities. Political Studies 61(3), 523-542.

Elkins, Z., Ginsburg, T., and Melton, J. (2014). Characteristics of National Constitutions, Version 2.0. Comparative Constitutions Project. Last modified: April 18, 2014. Available at: http://www.comparativeconstitutionsproject.org. 
Enriquez, E., and Centeno, M. (2012). State Capacity: Utilization, Durability, and the Role of Wealth vs. History. International and Multidisciplinary Journal of Social Sciences 1(2), $130-162$

Epifani, P., and Gancia, G. (2009). Openness, Government Size and the Terms of Trade. Review of Economic Studies 76, 629-668.

Erauskin, I. (2011). Financial Openness, Volatility, and the Size of Productive Government. SERIES 2(2), 233-253.

Evans, P.B. (1989). Predatory, Developmental, and Other Apparatuses: A Comparative Political Economy Perspective on the Third World State. Sociological Forum 4(4), 561-587.

Evans, P.B. (1995). Embedded Autonomy. Princeton, United States: Princeton University Press.

Evans, P.B., and Rauch, J.E.. (1999). A Cross-National Analysis of the Effects of "Weberian" State Structures on Economic Growth. American Sociological Review 64(5), 748-765.

Evans, P.B., Rueschemeyer, D. and Skocpol, T. (1985) Bringing the State Back In. New York: Cambridge University Press.

Filc, G., and Scartascini, C. (2012). Budgeting for Results in Latin America: Conditions for its Deployment and Development. Policy Brief IDB-PB-160. Washington, DC, United States: Inter-American Development Bank.

Franco Chuaire, M., and Scartascini, C. (2014). The Politics of Policies: Revisiting the Quality of Public Policies and Government Capabilities in Latin America and the Caribbean. Policy Brief IDB-PB-220. Washington, DC, United States: Inter-American Development Bank.

Fukuyama, F. (2013). What is Governance? Governance 26(3), 347-368.

Garrett, G., (1998a). Shrinking States? Globalization and Policy Autonomy in the OECD. Oxford Development Studies 26(1), 71-97. 
Garrett, G., (1998b). Global Markets and National Politics: Collision Course or Virtuous Circle? International Organization 52(4), 787-824

Garrett, G. (2001). Globalization and Government Spending around the World. Studies in Comparative International Development 3, 3-29.

Gavin, M. and Perotti, R. (1997). Fiscal Policy in Latin America. In: B.S. Bernanke and J. Rotemberg, editors. NBER Macroeconomics Annual 12. Cambridge, United States: MIT Press.

Gemmell, N., Kneller, R, and Sanz, I. (2008). Foreign Investment, International Trade and the Size and Structure of Public Expenditures. European Journal of Political Economy 24, $151-171$.

Gelos, G., and Ustyugova, Y. (2012). Inflation Responses to Commodity Price Shocks: How and Why Do Countries Differ? IMF Working Paper 12/225. Washington, DC, United States: International Monetary Fund.

Haber, S., North, D., and Weingast, B. (2008). Political Institutions and Financial Development. Stanford, United States: Stanford University Press.

Haggard, S. and Kaufman, R. (1992). The Politics of Economic Adjustment. Princeton: Princeton University Press.

Hamm, P., and King, L. (2010). Post-Manichean economics: foreign investment, state capacity, and economic development in transition economies. Working Paper 227, Political Economy Research Institute.

Hanson, J., and Sigman, R. (2013). Leviathan's Latent Dimensions: Measuring State Capacity for Comparative Political Research. Paper presented at the World Bank Political 
Economy Brown Bag Lunch Series, March 21, 2013, Syracuse University, Maxwell School of Government.

Hays, S., Ehrlich, D., and Peinhard, C. (2005). Government Spending and Public Support for Trade in the OECD: An Empirical Test of the Embedded Liberalism Thesis. International Organization 59, 473-494.

Herrendorf, B. (1999). Transparency, Reputation, and Credibility under Floating and Pegged Exchange Rates. Journal of International Economics 49(1), 31-50.

Huntington, S. (1968). Political Order in Changing Societies. New Haven, United States: Yale University Press.

ICRG. (2009). International Country Risk Guide (ICRG) researchers' dataset and codebook. [computer file]. 2009 ed. East Syracuse, NY: The PRS Group, Inc. [producer and distributor].

Inter-American Development Bank (IDB). (2005). The Politics of Policies: Economic and Social Progress in Latin America and the Caribbean 2006 Report. Washington, DC and Cambridge, United States: Inter-American Development Bank and Harvard University, David Rockefeller Center for Latin American Studies.

Iversen, T., and Soskice, D. (2014). Dualism and political coalitions: Inclusionary versus exclusionary reforms in an age of rising inequality. Prepared for presentation at the conference on The Future of Democratic Capitalism, June 16-18, 2011, Swiss Federal Institute of Technology, Zürich.

Katzenstein, P.J. (1985). Small States in World Markets: Industrial Policy in Europe. Ithaca, United States: Cornell University Press. 
Keefer, P., and Stasavage, D. (2013). The Limits of Delegation: Veto Players, Central Bank Independence, and the Credibility of Monetary Policy. American Political Science Review 97(3), 407-23.

Kittel, B., and Winner, H. (2005). How Reliable is Pooled Analysis in Political Economy? The Globalization-Welfare State Nexus Revisited. European Journal of Political Research 44, 269-293.

Kimakova, A. (2009). Government Size and Openness Revisited: The Case of Financial Globalization. Kyklos 62, 394-406.

Knotz, C., and Lindvall, J. (2014). Coalitions and Compensation: The Case of Unemployment Benefit Duration. Manuscript. Lund University.

Knutsen, C.H. (2013). Democracy, State Capacity, and Economic Growth. World Development $43,1-18$.

Kurtz, M. and Schrank, A. (2007). Growth and Governance: Models, Measures, and Mechanisms. Journal of Politics 69(2), 538-554.

Lapuente, V. (2007). A Political Economy Approach to Bureaucracies. Doctoral dissertation, University of Oxford.

Lecomte, H.B.S. (2002). Building Capacity to Trade: What are the Priorities? Paper presented at the International CTA Seminar 2002: "Meeting the Challenge of Effective ACP Participation in Agricultural Trade Negotiations: The Role of ICM," Brussels, Belgium, November 27-29.

Liberati, P. (2007). Trade Openness, Capital Openness and Government Size. Journal of Public Policy 27, 215-247. 
Loayza, N., and Raddatz, C. (2007). The Structural Determinants of External Vulnerability. World Bank Economic Review 21(3), 359-387.

López, R.E., Thomas, V., and Wang, Y. (2010). The Effect of Fiscal Policies on the Quality of Growth. Evaluation Brief 9. Washington, DC, United States: World Bank Independent Evaluation Group. Available at: http://ieg.worldbank.org/Data/reports/eb9 web.pdf

Mares, I. (2004). Economic Insecurity and Social Policy Expansion: Evidence from Interwar Europe. International Organization 58(4), 745-774.

Mares, I. (2005). Social Protection Around the World. External Insecurity, State Capacity, and Domestic Political Cleavages. Comparative Political Studies 38(6), 623-651.

Martin, C., and Steiner, N. (2013). Public Spending and Trade Liberalization: The Compensation Hypothesis Revisited. Paper prepared for presentation at the 71st Midwest Political Science Association (MPSA) Annual Conference, Chicago, United States, April 11-14.

Mansfield, E., and Reinhardt, E. (2008). International Institutions and the Volatility of International Trade. International Organization 62(4), 621-652.

Milesi-Ferreti, G.M., Perotti, R., and Rostagno, M. (2002). Electoral Systems and Public Spending. Quarterly Journal of Economics 127, 609-57.

Mueller, D. (2003). Public Choice III. Cambridge, United Kingdom: Cambridge University Press.

Noorruddin, I., and Rudra, N. (2014). Are Developing Countries Really Defying the Embedded Liberalism Compact? Forthcoming in World Politics 66(4).

Palanza, V., Scartascini, C., and Tommasi, M. (2014). Congressional Institutionalization: A Cross-National Comparison. Washington, DC, United States: Inter-American Development Bank. Forthcoming, Legislative Studies Quarterly. 
Pasadilla, G. (2005). Strengthening Trade Research Capacity for Policymaking and Negotiations. ARNeT Policy Brief 2. Bangkok, Thailand: United Nations Economic and Social Commission for Asia and the Pacific. Available at: http://artnet.unescap.org/pub/polbrief2.pdf

Persson, T., and Tabellini, G. (2003). The Economic Effects of Constitutions. Cambridge, United States: MIT Press.

Pritchett, L., Woolcock, M., and Andrews, M. (2010). Capability Traps? The Mechanisms of Persistent Implementation Failure. Working Paper234. Center for Global Development.

Ram, R. (2009). Openness, Country Size, and Government Size: Additional Evidence from a Large Cross-Country Panel. Journal of Public Economics 93, 213-218.

Rehm, P. (2009). Risks and Redistribution: An Individual-Level Analysis. Comparative Political Studies 42(7), 855-881.

Rockey, J. (2012). Reconsidering the Fiscal Effects of Constitutions. European Journal of Political Economy 28: 313-323.

Rodrik, D. (1998). Why Do More Open Economies Have Bigger Governments? Journal of Political Economy 106, 997-1032.

Rueschemeyer, D., and Evans, P. (1985). The State and Economic Transformation: Toward an Analysis of the Conditions Underlying Effective Intervention. In: P.B. Evans, D. Rueschemayer and T. Skocpol, editors. Bringing the State Back In. Cambridge, United Kindgom: Cambridge University Press.

Scartascini, C., Stein, E., and Tommasi, M. (2008). Political Institutions, State Capabilities and Public Policy: International Evidence. Research Department Working Paper 661. Washington, DC, United States: Inter-American Development Bank. 
Scartascini, C., Stein, E., and Tommasi, M. (2013). Political Institutions, Intertemporal Cooperation, and the Quality of Policies. Journal of Applied Economics 16(1), 1-32.

Scartascini, C., and Tommasi, M. (2010). The Political Economy of Productivity. In: C. Pagés, editor. The Age of Productivity. Development in the Americas Report. Washington, DC, United States: Inter-American Development Bank/Palgrave.

Scartascini, C., and Tommasi, M. (2012). The Making of Policy: Institutionalized or Not? American Journal of Political Science 56(4), 787-801.

Scheve, K., and Slaughter, M. (2007). A New Deal for Globalization. Foreign Affairs 86(4), 3447.

Skocpol, T. (1979). States and Social Revolutions: A Comparative Analysis of France, Russia, and China. Cambridge, United Kingdom: Cambridge University Press.

Skocpol. T., and Amenta, E. (1986). States and Social Policy. Annual Review of Sociology 12, 131-157.

Skocpol, T., and Finegold, K. (1982). State Capacity and Economic Intervention in the Early New Deal. Political Science Quarterly 97(2), 255-278

Stein, E., and Tommasi, M. (2007). The Institutional Determinants of State Capabilities in Latin America. In: F. Bourguignon and B. Pleskovic, editors. Annual World Bank Conference on Development Economics Regional: Beyond Transition. Washington, DC, United States: World Bank.

Teorell, J., Charron, N., Dahlberg, S., Holmberg, S., Rothstein, B., Sundin, P., and Svensson, R. (2013). The Quality of Government Dataset (QoG), version 15May13. University of Gothenburg: The Quality of Government Institute, http://www.qog.pol.gu.se.

UNCTAD. (2011). Policy actions to mitigate the impact of highly volatile prices and incomes on commodity dependent countries, and to facilitate value addition and greater participation 
in commodity value chains by commodity-producing countries. Note by the United Nations Conference on Trade and Development (UNCTAD) secretariat, Geneva, Switzerland, March 23-25.

Van de Walle, S. (2005). Measuring Bureaucratic Quality in Governance Indicators. Paper prepared for the 8th Public Management Research Conference, Los Angeles, United States, September 29-October 1.

Walter, S. (2010). Globalization and the Welfare State: Testing the Microfoundations of the Compensation Hypothesis. International Studies Quarterly 54(2), 403-26.

World Development Indicators (WDI). (2014). Washington, DC: World Bank. doi:10.1596/9781-4648-0163-1. License: Creative Commons Attribution CC BY 3.0 IGO.

Weaver, R.K., and Rockman, B.A. (1993). Do Institutions Matter? Government Capabilities in the United States and Abroad. Washington, DC, United States: Brookings Institution Press.

Weiss, L. (1998). The Myth of the Powerless State. Ithaca, United States: Cornell University Press. 


\section{APPENDIX}

\section{Table A1. Summary Statistics}

\begin{tabular}{|c|c|c|c|c|c|c|c|}
\hline Variable & Units & Source & Obs. & Mean & $\begin{array}{r}\text { Std. } \\
\text { deviation } \\
\end{array}$ & Min & Max \\
\hline \multicolumn{8}{|l|}{ Cross section analysis } \\
\hline Government consumption (1985-89) & $\%$ of GDP & WDI & 115 & 16.610 & 6.624 & 4.282 & 34.930 \\
\hline Government consumption (1990-92) & $\%$ of GDP & WDI & 118 & 16.284 & 7.503 & 3.144 & 56.840 \\
\hline Government consumption (2000-05) & $\%$ of GDP & WDI & 127 & 15.363 & 5.119 & 5.082 & 28.523 \\
\hline Openness $(1975-84)$ & $\%$ of GDP & WDI & 116 & 65.777 & 34.849 & 13.888 & 156.739 \\
\hline Openness (1980-89) & $\%$ of GDP & WDI & 119 & 64.669 & 33.453 & 13.967 & 163.867 \\
\hline Openness (1990-99) & $\%$ of GDP & WDI & 127 & 76.350 & 46.770 & 17.218 & 329.366 \\
\hline Terms of Trade (ToT) Volatility & $\begin{array}{l}\text { Standard deviation of the log- } \\
\text { differences in terms of trade } \\
\text { for the period 1980-99 }\end{array}$ & WDI and own estimates & 67 & 0.118 & 0.060 & 0.018 & 0.262 \\
\hline Bureaucratic Quality Index (1990-99) & $0-4$ & ICRG & 127 & 2.217 & 1.096 & 0 & 4 \\
\hline \multicolumn{8}{|l|}{ Instrumental variables } \\
\hline Age of democracy (age) & & Persson and Tabellini (PT) (2003) & 64 & 2.181 & 2.433 & 0 & 10 \\
\hline European settler mortality (log) (Settler mort.) & log total & Acemoglu et al. (2001) & 62 & 4.594 & 1.213 & 2.146 & 7.986 \\
\hline Ex-colony & Dummy variable & PT (2003) & 77 & 0.766 & 0.426 & 0 & 1 \\
\hline First democratic constitution $(m c)$ & $*$ & Rockey (2012) & 86 & 1.049 & 1.054 & 0.163 & 4.819 \\
\hline First democratic elections (me) & * & Rockey (2012) & 86 & 1.064 & 1.049 & 0.054 & 4.499 \\
\hline Historical political stability (Pol. Stab) & $0-1$ & Besley and Persson (2009) & 122 & 0.310 & 0.248 & 0 & 1 \\
\hline Judicial independence (judind) (1990) & Dummy variable & CCP (2008) & 53 & 0.755 & 0.434 & 0 & 1 \\
\hline Legislative oversight power (intexec) (1990) & $0-2^{*}$ & CCP (2008) & 51 & 0.961 & 0.720 & 0 & 2 \\
\hline Meritocratic recruitment of civil servants (civil) (1990) & Dummy variable & CCP (2008) & 52 & 0.173 & 0.382 & 0 & 1 \\
\hline Programmatic parties (rlc_avg) (1990) & Share of parties* & Cruz and Keefer (2013) and DPI (2012) & 124 & 0.373 & 0.335 & 0 & 1 \\
\hline \multicolumn{8}{|l|}{ Control variables } \\
\hline Real GDP per capita, PPP $(\log )(1975-84)$ & log total & WDI & 116 & 8.309 & 1.280 & 5.959 & 11.589 \\
\hline Real GDP per capita, PPP (log) (1980-89) & log total & WDI & 119 & 8.296 & 1.287 & 5.911 & 11.398 \\
\hline Real GDP per capita, PPP (log) (1990-99) & log total & WDI & 127 & 8.602 & 1.267 & 5.660 & 10.796 \\
\hline Dependency ratio (log) (1975-84) & $\%$ of working-age population & WDI & 126 & 4.366 & 0.235 & 3.775 & 4.724 \\
\hline Dependency ratio (log) (1980-89) & $\%$ of working-age population & WDI & 126 & 4.336 & 0.255 & 3.830 & 4.750 \\
\hline Dependency ratio (log) (1990-99) & $\%$ of working-age population & WDI & 127 & 4.181 & 0.267 & 3.670 & 4.757 \\
\hline Urbanization Rate (log) (1975-84) & $\%$ of total YUAERER & WDI & 126 & 3.563 & 0.695 & 1.423 & 4.556 \\
\hline Urbanization Rate (log) (1980-89) & $\%$ of total & WDI & 126 & 3.639 & 0.657 & 1.617 & 4.575 \\
\hline Urbanization Rate (log) (1990-99) & $\%$ of total & WDI & 127 & 3.919 & 0.522 & 2.252 & 4.605 \\
\hline pres & Dummy variable & PT (2003) & 126 & 0.563 & 0.498 & 0 & 1 \\
\hline maj & Dummy variable & PT (2003) & 123 & 0.635 & 0.464 & 0 & 1 \\
\hline Gastil & $1-7-2=1-2$ & Freedom House from PT (2003) & 77 & 2.437 & 1.214 & 1.000 & 4.889 \\
\hline Population (log) (2000) & log total & WDI & 127 & 9.293 & 1.585 & 5.639 & 14.050 \\
\hline federal & Dummy variable & PT (2003) & 75 & 0.173 & 0.381 & 0 & 1 \\
\hline Tariff rate (1990-99) & $\%$ of total imports & WDI & 127 & 2.709 & 4.763 & 0 & 27.211 \\
\hline OECD members & Dummy variable & & 127 & 0.189 & 0.393 & 0 & 1 \\
\hline Sub-Saharan Africa & Dummy variable & & 127 & 0.220 & 0.416 & 0 & 1 \\
\hline Latin America & Dummy variable & & 127 & 0.189 & 0.393 & 0 & 1 \\
\hline East Asia & Dummy variable & & 127 & 0.087 & 0.282 & 0 & 1 \\
\hline Socialist & Dummy variable & & 127 & 0.024 & 0.152 & 0 & 1 \\
\hline \multicolumn{8}{|l|}{ Placebo and validity analyses } \\
\hline Gini coefficient (1990-99) & $0-100$ & WDI & 110 & 41.925 & 10.236 & 24.70 & 74.33 \\
\hline Ethnolinguistic Fractionalization Index (1990-99) & $0-1$ & Quality of Government (QoG) & 186 & 0.438 & 0.258 & 0 & 0.930 \\
\hline Gastil (1990-99) & $1-7$ & Freedom House & 193 & 2.626 & 1.937 & 1 & 7 \\
\hline Checks (1990-99) & \# of veto players & DPI (2012) & 175 & 2.706 & 1.591 & 1 & 9.4 \\
\hline Bureaucratic Quality Index (1990-2010)^ & $0-4$ & ICRG & 554 & 2.322 & 1.156 & 0 & 4 \\
\hline Education $(1990-2010)^{\wedge}$ & years & Barro and Lee (2010) & 554 & 7.641 & 2.817 & 0.893 & 13.183 \\
\hline GDP pc growth (1990-2010)^ & growth rate & WDI & 554 & 2.533 & 4.354 & -50.236 & 19.171 \\
\hline Real GDP per capita, PPP $(\log )(1990-2010)^{\wedge}$ & log total & WDI & 554 & 9.160 & 1.247 & 4.956 & 11.754 \\
\hline Population (log) $(1990-2010)^{\wedge}$ & log total & WDI & 554 & 16.253 & 1.596 & 12.448 & 21.014 \\
\hline \multicolumn{8}{|l|}{ Panel Data Analysis } \\
\hline \multicolumn{8}{|l|}{ (5-year averages 1980-2004) } \\
\hline Government consumption & $\%$ of GDP & WDI & 246 & 12.996 & 5.067 & 4.080 & 40.655 \\
\hline Openness & $\%$ of GDP & WDI & 246 & 69.207 & 54.131 & 13.423 & 378.825 \\
\hline Bureaucratic Quality & $0-4$ & ICRG & 246 & 1.788 & 0.967 & 0 & 4 \\
\hline Terms of Trade (ToT) Volatility & $\begin{array}{l}\text { Standard deviation of the log- } \\
\text { differences in terms of trade } \\
\text { for each period }\end{array}$ & WDI & 245 & 0.098 & 0.084 & 0.000 & 0.493 \\
\hline \multicolumn{8}{|l|}{ Beginning of the period } \\
\hline Real GDP per capita, PPP (log) & log total & WDI & 246 & 7.997 & 1.077 & 5.562 & 10.586 \\
\hline Dependency ratio (log) & $\%$ of working-age population & WDI & 246 & 3.726 & 0.551 & 2.140 & 4.605 \\
\hline Urbanization Rate (log) & $\%$ of total & WDI & 246 & 4.331 & 0.239 & 3.614 & 4.717 \\
\hline
\end{tabular}


Table A2. First Stage Results: Instrumental Variables me and civil

\begin{tabular}{|c|c|c|c|c|c|c|c|c|c|c|c|c|}
\hline FIRST-STAGE VARIABLES & $\begin{array}{l}\text { Bur. Quality } \\
\text { (1) }\end{array}$ & $\begin{array}{c}\text { Open * Bur } \\
\text { (2) }\end{array}$ & $\begin{array}{c}\text { Bur. Quality } \\
\text { (3) }\end{array}$ & $\begin{array}{c}\text { Open * Bur } \\
(4)\end{array}$ & $\begin{array}{c}\text { Bur. Quality } \\
\text { (5) }\end{array}$ & $\begin{array}{c}\text { Open * Bur } \\
(6)\end{array}$ & $\begin{array}{l}\text { Bur. Quality } \\
\text { (7) }\end{array}$ & $\begin{array}{c}\text { Open * Bur } \\
(8)\end{array}$ & $\begin{array}{l}\text { Bur. Quality } \\
\text { (9) }\end{array}$ & $\begin{array}{c}\text { Open * Bur } \\
(10)\end{array}$ & $\begin{array}{c}\text { Bur. Quality } \\
\text { (11) }\end{array}$ & $\begin{array}{c}\text { Open * Bur } \\
(12)\end{array}$ \\
\hline \multirow[t]{2}{*}{ me } & $0.313^{* * *}$ & $-31.439 * * *$ & $1.133^{* *}$ & $-110.276^{*}$ & & & $0.260 * *$ & $-20.391 * *$ & 0.772 & $-108.211^{*}$ & & \\
\hline & $(0.110)$ & $(10.771)$ & $(0.514)$ & $(64.821)$ & & & $(0.104)$ & (10.114) & $(0.501)$ & $(54.428)$ & & \\
\hline \multirow[t]{2}{*}{ me $\times$ Openness (t-1) } & -0.001 & $0.637 * * *$ & -0.005 & $2.013^{* *}$ & & & -0.001 & $0.367^{* * *}$ & -0.004 & $1.483^{* *}$ & & \\
\hline & $(0.001)$ & $(0.146)$ & $(0.005)$ & $(0.789)$ & & & $(0.001)$ & $(0.106)$ & $(0.005)$ & $(0.644)$ & & \\
\hline \multirow[t]{2}{*}{$m e^{\wedge 2}$} & & & $-0.221^{*}$ & 20.092 & & & & & -0.136 & $22.054^{*}$ & & \\
\hline & & & $(0.118)$ & (15.914) & & & & & $(0.116)$ & (13.073) & & \\
\hline$m \mathrm{e}^{\wedge} 2 \times$ Openness $(\mathrm{t}-1)$ & & & 0.001 & $-0.335^{*}$ & & & & & 0.001 & $-0.268^{*}$ & & \\
\hline civil & & & $(0.001)$ & (0.188) & $\begin{array}{c}-1.156^{* * *} \\
(0.278)\end{array}$ & $\begin{array}{c}30.643 \\
(57.178)\end{array}$ & & & $(0.001)$ & $(0.150)$ & $\begin{array}{l}-1.255^{*} \\
(0.650)\end{array}$ & $\begin{array}{c}22.641 \\
(52.988)\end{array}$ \\
\hline civil x Openness (t-1) & & & & & $\begin{array}{l}0.014 * * * \\
(0.005)\end{array}$ & $\begin{array}{l}-0.935 \\
(0.962)\end{array}$ & & & & & $\begin{array}{l}0.014 \\
(0.010)\end{array}$ & $\begin{array}{l}-1.145 \\
(0.879)\end{array}$ \\
\hline Expanded Controls & No & No & No & No & No & No & Yes & Yes & Yes & Yes & Yes & Yes \\
\hline Excluded Instruments & $\mathrm{me}, \mathrm{me}^{*}$ openness & me, me*openness & $\begin{array}{c}\text { me, me*openness } \\
m \mathrm{e}^{\wedge} 2 \\
\mathrm{me}^{\wedge} 2^{*} \text { openness }\end{array}$ & $\begin{array}{c}\text { me, me*openness, } \\
m \mathrm{e}^{\wedge} 2, \\
\mathrm{me}^{\wedge} 2^{*} \text { openness }\end{array}$ & $\begin{array}{c}\text { civil, } \\
\text { civil }{ }^{*} \text { openness }\end{array}$ & $\begin{array}{c}\text { civil, } \\
\text { ivil*openness }\end{array}$ & $\begin{array}{c}\text { me, } \\
\text { me*openness }\end{array}$ & $\begin{array}{c}\text { me, } \\
\text { me*openness }\end{array}$ & $\begin{array}{c}\text { me, me*openness, } \\
\text { me } 2, \\
\mathrm{me}^{\wedge} 2^{*} \text { openness }\end{array}$ & 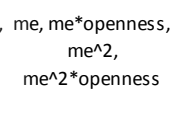 & $\begin{array}{c}\text { civil, } \\
\text { civil }{ }^{*} \text { openness }\end{array}$ & $\begin{array}{c}\text { civil, } \\
\text { civil*openness }\end{array}$ \\
\hline Observations & 86 & 86 & 86 & 86 & 52 & 52 & 77 & 77 & 77 & 77 & 34 & 34 \\
\hline Adjusted R-squared & 0.746 & 0.895 & 0.754 & 0.907 & 0.882 & 0.905 & 0.764 & 0.922 & 0.761 & 0.925 & 0.900 & 0.978 \\
\hline $\mathrm{F}$ & 5.030 & 9.920 & 3.440 & 8.840 & 9.910 & 1.460 & 3.170 & 6.130 & 1.800 & 5.040 & 4.680 & 7.340 \\
\hline Prob $>F$ & 0.009 & 0.000 & 0.012 & 0.000 & 0.000 & 0.245 & 0.049 & 0.004 & 0.141 & 0.002 & 0.023 & 0.005 \\
\hline \multicolumn{13}{|c|}{ A-P F test of weak excluded instruments } \\
\hline F & 9.960 & 19.770 & 4.590 & 11.740 & 19.710 & 2.580 & 5.720 & 11.340 & 2.120 & 5.920 & 4.630 & 6.680 \\
\hline Prob>F & 0.002 & 0.000 & 0.005 & 0.000 & 0.000 & 0.116 & 0.020 & 0.001 & 0.107 & 0.001 & 0.045 & 0.019 \\
\hline
\end{tabular}


Figure A1. Marginal Effect of Trade Openness on Government Consumption along Bureaucratic Quality: Instrumental Variables

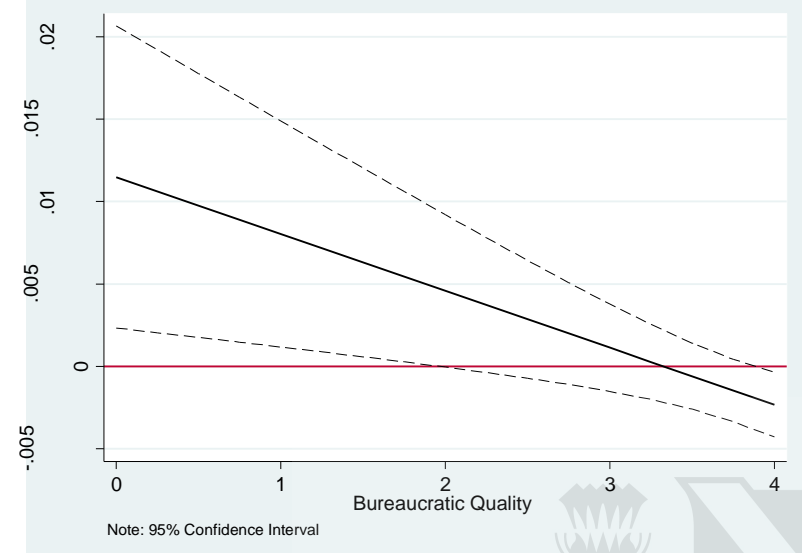

a. Column 5 of Table 4: $m e \& m e^{\wedge} 2$

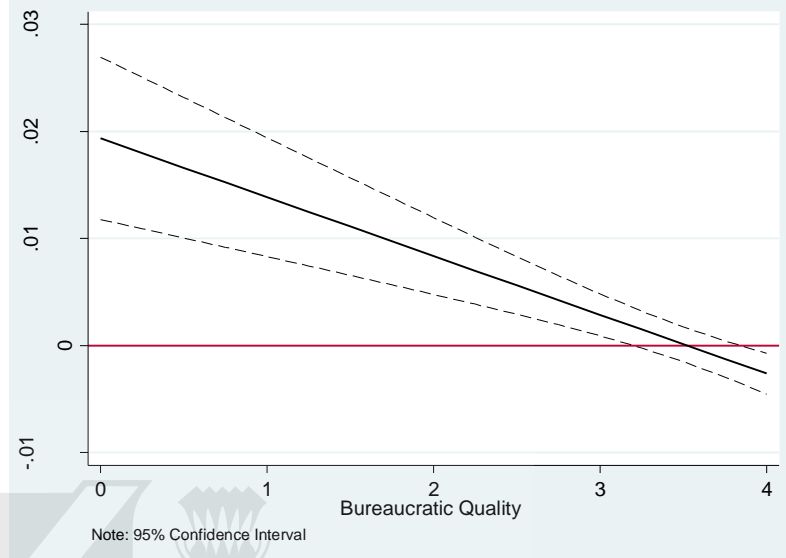

b. Column 6 of Table 4: civil 
State Capacity and the Quality of Policies

Revisiting the Relationship between Openness and Government Size

\author{
ONLINE APPENDIX
}

\title{
INDEX
}

1. Evaluating the bureaucratic quality measure

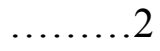

2. Replicating Rodrik's results

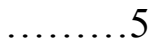

3. Running Regressions in Rodrik's sample

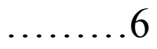

4. Splitting the sample results

5. Panel data analysis - Random effects regressions

6. Results over time

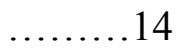

7. Instrumental variables - Expanded set of instruments

8. Robustness results - Placebos 


\section{Evaluating the bureaucratic quality measure.}

As we describe in the paper, there may be some concerns about the validity of the bureaucratic quality measure because it is generated from survey responses. To address some of the concern we follow mostly the strategy in Kurtz and Schrank (2007). Basically, this methodology tries to evaluate whether variables that relate to good governance suffer from (1) perceptual biases, (2) adverse selection in sampling, (3) and conceptual conflation with economic policy choices. To reduce these concerns, we have checked:

First, if this indicator correlates well with other variables that try to proxy similar processes and more objective indicators. This indicator correlates well (around 0.6) with Evans and Rauch (1999) measure of bureaucratic quality. Additionally, this indicator of bureaucratic quality also correlates well with other dimensions of state capabilities that have been shown to relate to higher quality of policymaking in smaller country samples (within Latin America).

Second, we examine the stability of the measure across time, given that the quality of the bureaucracy depends on the accumulation of investments, therefore, it should change only gradually. Otherwise, the measure may be picking up either cyclical sentiment (such as economic or political fluctuations), or de jure changes (such as the approval of a reform law). We have performed several checks; all of them point in the direction of very high stability. We have checked the year-to-year correlation, which is around 0.9, we have checked unit root tests, and we have also run a panel regression with country fixed effects of the dependent variable on its lag. As it can be observed in the following table, the regression coefficient of the lag dependent variable is 0.85 and the adjusted $R^{2}$ is above 0.75 . The fact that the variable is stable even beyond the first lag is also even more encouraging, because it shows that it may follow the type of processes we have discussed in the paper. 
Table 1.1. Stability of the dependent variable

\begin{tabular}{|c|c|c|c|c|c|c|}
\hline \multirow{2}{*}{ VARIABLES } & \multicolumn{6}{|c|}{ Bureaucratic Quality (t) } \\
\hline & $(1)$ & $(2)$ & $(3)$ & (4) & $(5)$ & $(6)$ \\
\hline Bureaucratic Quality (t-1) & $\begin{array}{c}0.850^{* * *} \\
(0.010)\end{array}$ & & & $\begin{array}{c}0.860^{* * *} \\
(0.010)\end{array}$ & & \\
\hline Bureaucratic Quality (t-2) & & $\begin{array}{c}0.687^{* * *} \\
(0.015)\end{array}$ & & & $\begin{array}{c}0.706^{* * *} \\
(0.015)\end{array}$ & \\
\hline Bureaucratic Quality (t-3) & & & $\begin{array}{c}0.559 * * * \\
(0.017)\end{array}$ & & & $\begin{array}{c}0.581 * * * \\
(0.017)\end{array}$ \\
\hline Constant & $\begin{array}{c}0.333^{* * *} \\
(0.023)\end{array}$ & $\begin{array}{c}0.694^{* * *} \\
(0.032)\end{array}$ & $\begin{array}{c}0.976 * * * \\
(0.037)\end{array}$ & $\begin{array}{c}0.321 * * * \\
(0.024)\end{array}$ & $\begin{array}{c}0.671^{* * *} \\
(0.034)\end{array}$ & $\begin{array}{c}0.956^{* * *} \\
(0.039)\end{array}$ \\
\hline Observations & 2,117 & 2,100 & 2,083 & 1,919 & 1,902 & 1,885 \\
\hline Adjusted R-squared & 0.774 & 0.531 & 0.360 & 0.791 & 0.560 & 0.386 \\
\hline Number of Countries & 140 & 140 & 140 & 127 & 127 & 127 \\
\hline Fixed Effects & Yes & Yes & Yes & Yes & Yes & Yes \\
\hline Sample & Whole & Whole & Whole & Broad & Broad & Broad \\
\hline
\end{tabular}

Finally, in order to examine whether the measure is correlated to structural or cyclical factors, we run a set of regressions of the measure on (the log of) GDPpc, GDPpc growth, a proxy for the size of the country such as (the log of) population, and education. We expect, as $\mathrm{KZ}$ did, a positive correlation of bureaucratic quality with the level of development and the level of education of the adult population. Our dependent variable should not be correlated to shortterm fluctuations; therefore, we expect the coefficient for growth to be not significant. Empirical results for several cross-sections (each one for a different 5-year period) and a panel, as presented in the next table, confirm our priors. 
Table 1.2. Convergent and Discriminant Validity

\begin{tabular}{|c|c|c|c|c|}
\hline VARIABLES & $\begin{array}{c}(1) \\
\text { Bureaucratic Quality } \\
1995\end{array}$ & $\begin{array}{c}\text { (2) } \\
\text { Bureaucratic Quality } \\
2005\end{array}$ & $\begin{array}{c}\text { (3) } \\
\text { Bureaucratic Quality } \\
2010\end{array}$ & $\begin{array}{c}\text { (4) } \\
\text { Random Effects } \\
1990-2010\end{array}$ \\
\hline log GDP per capita & $\begin{array}{c}0.486^{* * *} \\
(0.096)\end{array}$ & $\begin{array}{c}0.453^{* * *} \\
(0.091)\end{array}$ & $\begin{array}{c}0.382^{* * *} \\
(0.093)\end{array}$ & $\begin{array}{c}0.557^{* * *} \\
(0.063)\end{array}$ \\
\hline Education & $\begin{array}{l}0.085^{*} \\
(0.044)\end{array}$ & $\begin{array}{c}0.130 * * * \\
(0.041)\end{array}$ & $\begin{array}{c}0.141^{* * *} \\
(0.038)\end{array}$ & $\begin{array}{c}0.072^{* * *} \\
(0.028)\end{array}$ \\
\hline GDP growth rate $(\mathrm{t}-1, \mathrm{t}-2)$ & $\begin{array}{c}0.014 \\
(0.018)\end{array}$ & $\begin{array}{c}-0.040 * * \\
(0.020)\end{array}$ & $\begin{array}{l}-0.007 \\
(0.023)\end{array}$ & $\begin{array}{l}-0.001 \\
(0.007)\end{array}$ \\
\hline log population & $\begin{array}{l}0.092^{*} \\
(0.049)\end{array}$ & $\begin{array}{c}0.070 \\
(0.048)\end{array}$ & $\begin{array}{c}0.031 \\
(0.046)\end{array}$ & $\begin{array}{c}0.079 * * \\
(0.037)\end{array}$ \\
\hline Constant & $\begin{array}{c}-3.970 * * * \\
(1.115)\end{array}$ & $\begin{array}{c}-3.958^{* * *} \\
(1.112)\end{array}$ & $\begin{array}{c}-2.916^{* * *} \\
(1.049)\end{array}$ & $\begin{array}{c}-4.541^{* * *} \\
(0.816)\end{array}$ \\
\hline Observations & 105 & 117 & 117 & 554 \\
\hline $\begin{array}{l}\text { Adjusted R-squared } \\
\text { Number of countries }\end{array}$ & 0.504 & 0.513 & 0.528 & $\begin{array}{c}0.519 \\
118\end{array}$ \\
\hline
\end{tabular}

Note: adapted from Kurtz and Schrank (2007). GDP per capita expressed as thousands of U.S dollars at PPP for the year in question.

Education is measured as the average number of years of schooling in the over-15 population five years before the year in question. GDP rate is the two-year average rate of GDP per capita growth, for the last two years prior to the measurement of bureaucratic quality. For details and sources, see the appendix.

Standard errors in parentheses

${ }^{* * *} p<0.01,{ }^{* *} p<0.05,{ }^{*} p<0.1$ 


\section{Replicating Rodrik's Results}

The final dataset used by the author is not available and given the amount of time that has passed since the paper was first published, some of the sources have been updated using new methodologies. Acquiring the actual data used to create the original dataset thus proved to be difficult. However, we replicated the original dataset to the best of our ability and performed our baseline exercises in Rodrik's sample period finding the same qualitative results. The following table presents both Rodrik's results and our replication.

Table 2.1. Rodrik's Results and Replication

\begin{tabular}{|c|c|c|c|c|}
\hline \multirow[t]{2}{*}{ VARIABLES } & \multicolumn{2}{|c|}{$\begin{array}{c}\text { Log Government } \\
\text { Consumption (\% of GDP) } \\
1985-89\end{array}$} & \multicolumn{2}{|c|}{$\begin{array}{c}\text { Log Government } \\
\text { Consumption (\% of GDP) } \\
1990-92\end{array}$} \\
\hline & $\begin{array}{c}\text { Rodrik (1998) } \\
\text { (1) }\end{array}$ & $\begin{array}{c}\text { Replication } \\
\text { (2) }\end{array}$ & $\begin{array}{c}\text { Rodrik (1998) } \\
\text { (3) }\end{array}$ & $\begin{array}{c}\text { Replication } \\
(4)\end{array}$ \\
\hline Log Openness (t-1) & $\begin{array}{c}0.205^{* * *} \\
(0.057)\end{array}$ & $\begin{array}{c}0.370 * * * \\
(0.053)\end{array}$ & $\begin{array}{c}0.223^{* * *} \\
(0.064)\end{array}$ & $\begin{array}{c}0.276^{* * *} \\
(0.062)\end{array}$ \\
\hline log GDP per capita (t-1) & $\begin{array}{l}0.105^{*} \\
(0.063)\end{array}$ & $\begin{array}{c}0.109 * \\
(0.057)\end{array}$ & $\begin{array}{l}-0.030 \\
(0.084)\end{array}$ & $\begin{array}{c}0.201^{* * *} \\
(0.065)\end{array}$ \\
\hline log dependency ratio (t-1) & $\begin{array}{c}0.630^{* * *} \\
(0.193)\end{array}$ & $\begin{array}{c}0.804^{* * *} \\
(0.199)\end{array}$ & $\begin{array}{c}0.642^{* * *} \\
(0.241)\end{array}$ & $\begin{array}{c}0.579 * * * \\
(0.208)\end{array}$ \\
\hline log urbanization rate (t-1) & $\begin{array}{l}-0.136^{*} \\
(0.075)\end{array}$ & $\begin{array}{l}-0.048 \\
(0.070)\end{array}$ & $\begin{array}{l}-0.203 * * \\
(0.093)\end{array}$ & $\begin{array}{l}-0.093 \\
(0.085)\end{array}$ \\
\hline OECD & $\begin{array}{l}-0.014 \\
(0.122)\end{array}$ & $\begin{array}{c}0.358^{* * *} \\
(0.116)\end{array}$ & $\begin{array}{l}-0.007 \\
(0.144)\end{array}$ & $\begin{array}{c}0.133 \\
(0.124)\end{array}$ \\
\hline Sub-Saharan Africa & $\begin{array}{c}-0.239 * * \\
(0.101)\end{array}$ & $\begin{array}{l}-0.030 \\
(0.095)\end{array}$ & $\begin{array}{l}-0.107 \\
(0.118)\end{array}$ & $\begin{array}{c}-0.010 \\
(0.107)\end{array}$ \\
\hline Latin America & $\begin{array}{c}-0.218^{* *} \\
(0.094)\end{array}$ & $\begin{array}{c}-0.203^{* *} \\
(0.089)\end{array}$ & $\begin{array}{l}-0.171 \\
(0.113)\end{array}$ & $\begin{array}{c}-0.368^{* * *} \\
(0.096)\end{array}$ \\
\hline East Asia & $\begin{array}{c}-0.338 * * \\
(0.130)\end{array}$ & $\begin{array}{c}-0.118 \\
(0.103)\end{array}$ & $\begin{array}{l}-0.206 \\
(0.140)\end{array}$ & $\begin{array}{l}-0.181 \\
(0.118)\end{array}$ \\
\hline Socialist & $\begin{array}{c}0.092 \\
(0.100)\end{array}$ & $\begin{array}{l}0.346^{*} \\
(0.196)\end{array}$ & $\begin{array}{c}0.169 \\
(0.130)\end{array}$ & $\begin{array}{c}0.339 \\
(0.267)\end{array}$ \\
\hline Constant & $\begin{array}{c}3.786^{* * *} \\
(0.383)\end{array}$ & $\begin{array}{c}-2.193 * \\
(1.135)\end{array}$ & $\begin{array}{c}3.289 * * * \\
(0.536)\end{array}$ & $\begin{array}{c}-2.193 * \\
(1.135)\end{array}$ \\
\hline Observations & 125 & 133 & 103 & 133 \\
\hline Adjusted R-squared & 0.458 & 0.348 & 0.430 & 0.348 \\
\hline
\end{tabular}




\section{Running Regressions in Rodrik's Sample}

We run the empirical analysis in two different samples, a broad sample that includes those countries for which data was available in the updated sources and a narrow sample that includes only those countries that are thought to belong to Rodrik's sample according to the data sources used in his work. Although, obtaining the actual data used to create the original dataset proved to be difficult, we replicated it to the best of our ability. While in the text we have concentrated on the results based on the first set of countries, here we present the results using Rodrik's sample.

In Column 2 of Table 3.1 we have included the interaction term between bureaucratic quality and openness to Rodrik's baseline regression presented in column 1. Figure 3.1 plots the marginal effects of interest which, similar to the results with the broad sample, turns out to be positive and significant for countries with low state capacities but dissipates as these increase. Furthermore, once the three-way interaction term between openness, bureaucratic quality, and TOT volatility is included (Column 4), the effect remains. Figure 3.2 summarizes the marginal effect of openness for different values of bureaucratic quality when TOT volatility is set at its $50^{\text {th }}$ percentile. Table 3.2 and Figure 3.3 show that our results remain in a panel setting even after including a full set of time and country fixed effects. 
Table 3.1. Accounting for Government Capabilities and Terms of Trade Volatility:

\section{Cross Section, Rodrik's Sample}

\begin{tabular}{|c|c|c|c|c|}
\hline \multirow{2}{*}{ VARIABLES } & \multicolumn{4}{|c|}{ Log Government Consumption (\% of GDP) 2000-05 } \\
\hline & $(1)$ & (2) & (3) & (4) \\
\hline \multirow[t]{2}{*}{ Openness (t-1) } & $0.002 * *$ & $0.004 * *$ & 0.004 & 0.0001 \\
\hline & $(0.001)$ & $(0.002)$ & $(0.003)$ & $(0.006)$ \\
\hline \multirow[t]{2}{*}{ Bureaucratic Quality (t-1) } & & 0.099 & & 0.008 \\
\hline & & $(0.073)$ & & $(0.204)$ \\
\hline \multirow[t]{2}{*}{ Openness (t-1) x Bureaucratic Quality (t-1) } & & -0.001 & & 0.004 \\
\hline & & $(0.001)$ & & $(0.003)$ \\
\hline \multirow[t]{2}{*}{ ToT Volatility (t-1) } & & & 0.391 & -1.514 \\
\hline & & & $(1.551)$ & $(2.658)$ \\
\hline \multirow[t]{2}{*}{ Openness (t-1) x ToT Volatility (t-1) } & & & -0.028 & 0.051 \\
\hline & & & $(0.023)$ & $(0.045)$ \\
\hline Bureaucratic Quality (t-1) x ToT Volatility (t-1) & & & & 1.924 \\
\hline & & & & $(1.805)$ \\
\hline & & & & $-0.068 * *$ \\
\hline Openness (t-1) x Bureaucratic Quality (t-1) x ToT Volatility (t-1) & & & & $(0.031)$ \\
\hline Observations & 101 & 101 & 63 & 63 \\
\hline Adjusted R-squared & 0.357 & 0.357 & 0.122 & 0.261 \\
\hline
\end{tabular}

Note: Other controls not shown in the table: log GDP per capita (t-1), log dependency ratio (t-1), log urbanization rate (t-1), and dummy variables for OECD, Sub-Saharan Africa, Latin America, East Asia, and Socialist countries. $t-1$ corresponds to the period 1990-99, except for ToT Volatility where the period 1980-99 is considered. A constant term was included in all regressions.

Standard errors in parentheses. ${ }^{* * *} p<0.01,{ }^{* *} p<0.05, * p<0.1$ 
Figure 3.1. Marginal Effect of Trade Openness on Government Consumption along Bureaucratic Quality: Cross Section, Rodrik's Sample

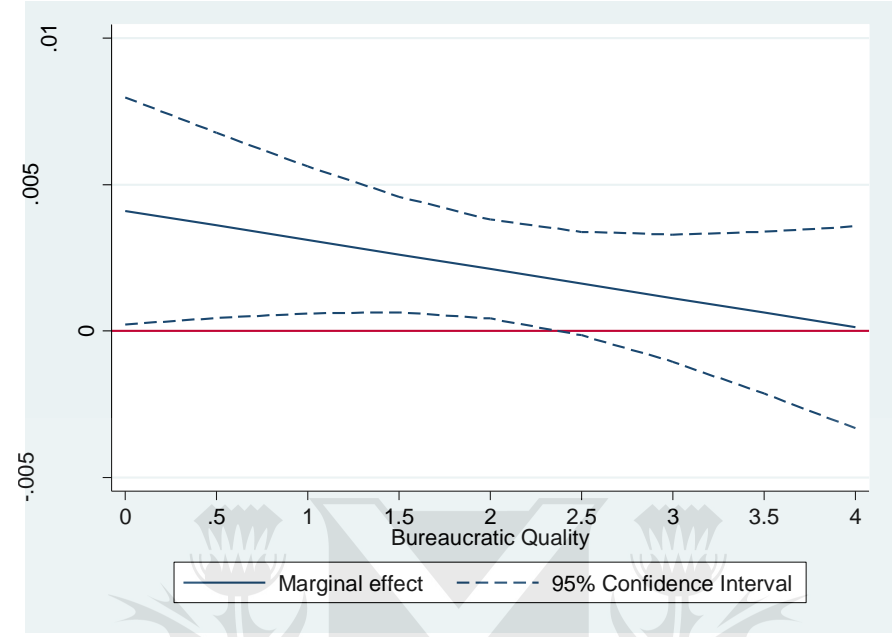

Note: The figure corresponds to the regression in column 2 of Table 3.1.

Figure 3.2. Marginal Effect of Trade Openness on Government Consumption along Bureaucratic Quality: ToT Volatility at $50^{\text {th }}$ Percentile, Rodrik's Sample

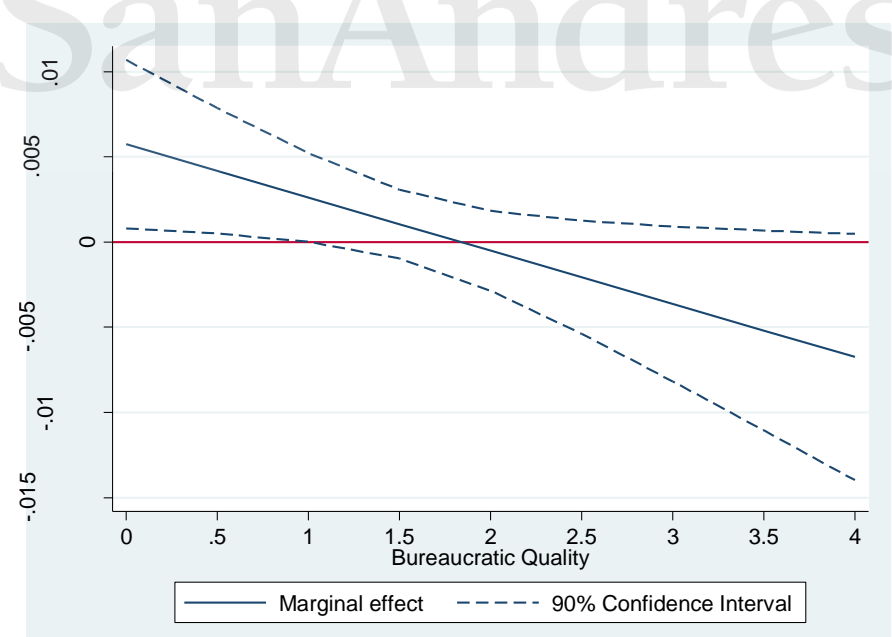

Note: The figure corresponds to the regression in column 4 of Table 3.1 . 
Table 3.2. Accounting for Government Capabilities and Terms of Trade Volatility:

Panel Data, Rodrik's Sample

\begin{tabular}{|c|c|c|c|c|}
\hline \multirow{2}{*}{ VARIABLES } & \multicolumn{4}{|c|}{ Log Government Consumption (\% of GDP) } \\
\hline & $(1)$ & $(2)$ & (3) & (4) \\
\hline \multirow[t]{2}{*}{ Openness (t-1) } & $0.004 * *$ & $0.007 * * *$ & $0.006 * * *$ & $0.008^{* * *}$ \\
\hline & $(0.002)$ & $(0.003)$ & $(0.001)$ & $(0.002)$ \\
\hline \multirow[t]{2}{*}{ ToT Volatility (t-1) } & & 0.594 & & 0.613 \\
\hline & & $(0.704)$ & & $(0.667)$ \\
\hline \multirow[t]{2}{*}{ Openness (t-1) x ToT Volatility (t-1) } & & $-0.022^{*}$ & & $-0.020^{*}$ \\
\hline & & $(0.013)$ & & $(0.012)$ \\
\hline \multirow[t]{2}{*}{ Bureaucratic Quality (t-1) } & $0.107^{* *}$ & $0.162^{* *}$ & $0.139 * * *$ & $0.198^{* * *}$ \\
\hline & $(0.049)$ & $(0.069)$ & -0.042 & $(0.061)$ \\
\hline \multirow[t]{2}{*}{ Openness (t-1) x Bureaucratic Quality (t-1) } & $-0.001 * *$ & $-0.003 * * *$ & $-0.002 * * *$ & $-0.003 * * *$ \\
\hline & $(0.001)$ & $(0.001)$ & -0.001 & $(0.001)$ \\
\hline \multirow[t]{2}{*}{ Bureaucratic Quality (t-1) x ToT Volatility (t-1) } & & -0.604 & & -0.597 \\
\hline & & $(0.450)$ & & $(0.428)$ \\
\hline \multicolumn{5}{|l|}{ Openness (t-1) x Bureaucratic Quality (t-1) x ToT } \\
\hline \multirow[t]{2}{*}{ Volatility $(\mathrm{t}-1)$} & & 0.012 & & 0.011 \\
\hline & & $(0.008)$ & & -0.008 \\
\hline Estimation & Fixed Effects & Fixed Effects & Random Effects & Random Effects \\
\hline Hausman Test (Prob>chi2) & & & $0.025^{\wedge}$ & $0.000^{\wedge}$ \\
\hline Observations & 236 & 236 & 236 & 236 \\
\hline Number of countries & 64 & 64 & 64 & 64 \\
\hline \multicolumn{5}{|c|}{$\begin{array}{l}\text { Note: Regressions in columns } 1 \text { and } 2 \text { correspond to a Fixed Effects (within) model with time (period) dummies. Regressions in columns } 3 \text { and } 4 \\
\text { correspond to a Random Effects model with time (period) dummies. Data are period averages for 1980-84, 1985-89,1990-94, 1995-99, 2000-04 (except } \\
\text { for the additional controls which belong to the beginning of each period). }\end{array}$} \\
\hline
\end{tabular}

\section{Figure 3.3. Marginal Effect of Trade Openness on Government Consumption}

along Bureaucratic Quality: Panel Data, Rodrik's Sample

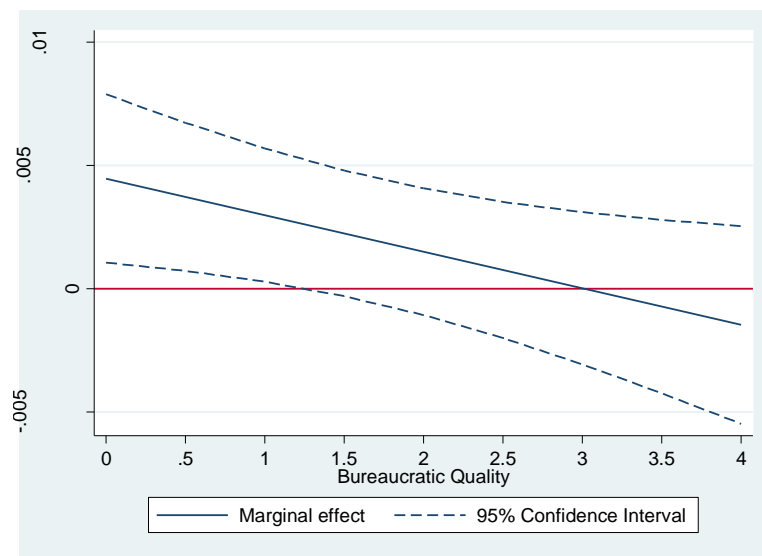

a. Column 1 of Table 3.2

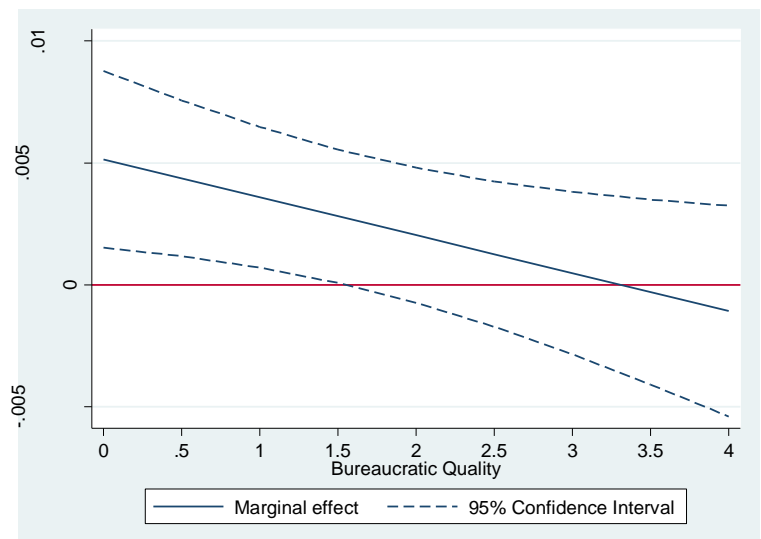

b. Column 2 of Table 3.2 (TOT Volatility $50^{\text {th }}$ p.) 


\section{Splitting the sample results}

As an alternative empirical strategy, we also split the sample among those countries with high and low bureaucratic quality. For splitting the sample according to the bureaucratic quality index, we use k-means and the L1-norm. k-means is the better known and more widespread clustering procedure that yields a partition of the space and it generates uniformly consistent estimations of the underlying density. The composition of the clusters is presented in Table 4.1. After running the procedure 100 times and assigning a different random seed each time, we find that the clusters are stable and never change, i.e., the resulting groupings are always the same.

Table 4.1. Composition of the clusters

\begin{tabular}{|c|c|c|c|c|}
\hline \multicolumn{2}{|c|}{ High Bureaucratic Quality } & \multicolumn{3}{|c|}{ Low Bureaucratic Quality } \\
\hline Australia & Jamaica & Albania & Haiti & Romania \\
\hline Austria & Japan & Algeria & Honduras & Russia \\
\hline Bahamas & Kenya & Argentina & Indonesia & Saudi Arabia \\
\hline Bahrain & Korea, Republic of & AERER Armenia & Iran & Senegal \\
\hline Belgium & Luxembourg & Azerbaijan & Jordan & Sierra Leone \\
\hline Brazil & Malaysia & Bangladesh & Kazakhstan & Sri Lanka \\
\hline Cameroon & Malta & Belarus & Kuwait & Sudan \\
\hline Canada & Namibia & Bolivia & Latvia & Suriname \\
\hline Colombia & Netherlands & Botswana & Lebanon & Syria \\
\hline Cote d’Ivoire & New Zealand & Bulgaria & Liberia & Tanzania \\
\hline Cyprus & Norway & Burkina Faso & Libya & Togo \\
\hline Czech Republic & Oman & Chile & Lithuania & Trinidad \& Tobago \\
\hline Denmark & Papua New Guinea & China & Madagascar & Tunisia \\
\hline Estonia & Poland & Congo, Dem. Rep. & Malawi & Uganda \\
\hline Finland & Portugal & Congo, Republic of & Mali & Ukraine \\
\hline France & Singapore & Costa Rica & Mexico & Uruguay \\
\hline Gabon & Slovak Republic & Croatia & Moldova & Venezuela \\
\hline Germany & Slovenia & Dominican Republic & Mongolia & Vietnam \\
\hline Ghana & South Africa & Ecuador & Morocco & Yemen \\
\hline Greece & Spain & Egypt & Mozambique & Zambia \\
\hline Hong Kong & Sweden & El Salvador & Nicaragua & \\
\hline Hungary & Switzerland & Ethiopia & Niger & \\
\hline Iceland & Thailand & Gambia, The & Pakistan & \\
\hline India & Turkey & Guatemala & Panama & \\
\hline Ireland & United Kingdom & Guinea & Paraguay & \\
\hline Israel & United States & Guinea-Bissau & Peru & \\
\hline Italy & & Guyana & Philippines & \\
\hline
\end{tabular}


As it can be observed in Table 4.2, while we find no significant relationship between trade and size of the government for the set of countries with high capabilities (53 countries), we find a positive and statistically significant coefficient for those countries that clustered among the weakest (74 countries). This result holds in both samples.

Table 4.2. Regressions results. Splitting the sample between high and low bureaucratic quality

\begin{tabular}{|c|c|c|c|c|}
\hline \multirow{4}{*}{ VARIABLES } & \multicolumn{4}{|c|}{ Log Government Consumption (\% of GDP) 2000-05 } \\
\hline & \multicolumn{2}{|c|}{ Broad Sample } & \multicolumn{2}{|c|}{ Rodrik's Sample } \\
\hline & (1) & $(2)$ & (3) & (4) \\
\hline & High & Low & High & Low \\
\hline \multirow[t]{2}{*}{ Openness (t-1) } & -0.001 & $0.004 * * *$ & -0.001 & $0.003^{* * *}$ \\
\hline & $(0.001)$ & $(0.001)$ & $(0.001)$ & $(0.001)$ \\
\hline \multirow[t]{2}{*}{ log GDP per capita (t-1) } & $0.185^{* *}$ & $0.182 * * *$ & 0.131 & $0.154^{* *}$ \\
\hline & $(0.089)$ & $(0.061)$ & $(0.102)$ & $(0.072)$ \\
\hline \multirow[t]{2}{*}{ log dependency ratio (t-1) } & 0.092 & -0.057 & 0.084 & -0.137 \\
\hline & $(0.296)$ & $(0.223)$ & $(0.346)$ & $(0.312)$ \\
\hline \multirow[t]{2}{*}{ log urbanization rate $(\mathrm{t}-1)$} & -0.187 & 0.019 & -0.055 & -0.015 \\
\hline & $(0.153)$ & $(0.089)$ & $(0.186)$ & $(0.097)$ \\
\hline \multirow[t]{2}{*}{ OECD } & -0.128 & & -0.076 & \\
\hline & $(0.107)$ & & (0.129) & \\
\hline \multirow[t]{2}{*}{ Sub-Saharan Africa } & $-0.290 *$ & $0.287^{* *}$ & $-0.351 *$ & 0.187 \\
\hline & $(0.160)$ & $(0.124)$ & (0.183) & $(0.138)$ \\
\hline \multirow[t]{2}{*}{ Latin America } & $-0.245^{*}$ & -0.106 & -0.235 & -0.150 \\
\hline & $(0.146)$ & $(0.090)$ & $(0.158)$ & $(0.111)$ \\
\hline \multirow[t]{2}{*}{ East Asia } & $-0.359 * * *$ & -0.076 & $-0.282 *$ & -0.264 \\
\hline & $(0.119)$ & $(0.166)$ & (0.149) & $(0.220)$ \\
\hline \multirow[t]{2}{*}{ Socialist } & & 0.198 & & 0.275 \\
\hline & & $(0.184)$ & & $(0.239)$ \\
\hline \multirow[t]{2}{*}{ Constant } & 1.727 & 0.975 & 1.661 & 1.759 \\
\hline & $(1.596)$ & $(1.217)$ & $(1.820)$ & $(1.683)$ \\
\hline Observations & 53 & 74 & 44 & 57 \\
\hline Adjusted R-squared & 0.339 & 0.297 & 0.311 & 0.233 \\
\hline
\end{tabular}




\section{Panel Data Analysis: Random Effects Regressions}

The panel regressions were run using both fixed effects and random effects. As mentioned in the paper's core results, the Hausman test favors the fixed effects model. However, we present the random effects model in Table 2 of the paper (columns 3 and 4) and the respective figures in this appendix. Figure 5 shows that past exposure to external risk is a statistically significant determinant of government consumption when the quality of the bureaucracy is low. As in the fixed effects model, this effect dissipates as the state capacities increase.

\section{Figure 5.1. Marginal Effect of Trade Openness on Government Consumption along Bureaucratic Quality: Panel Data, Random Effects, Broad Sample}
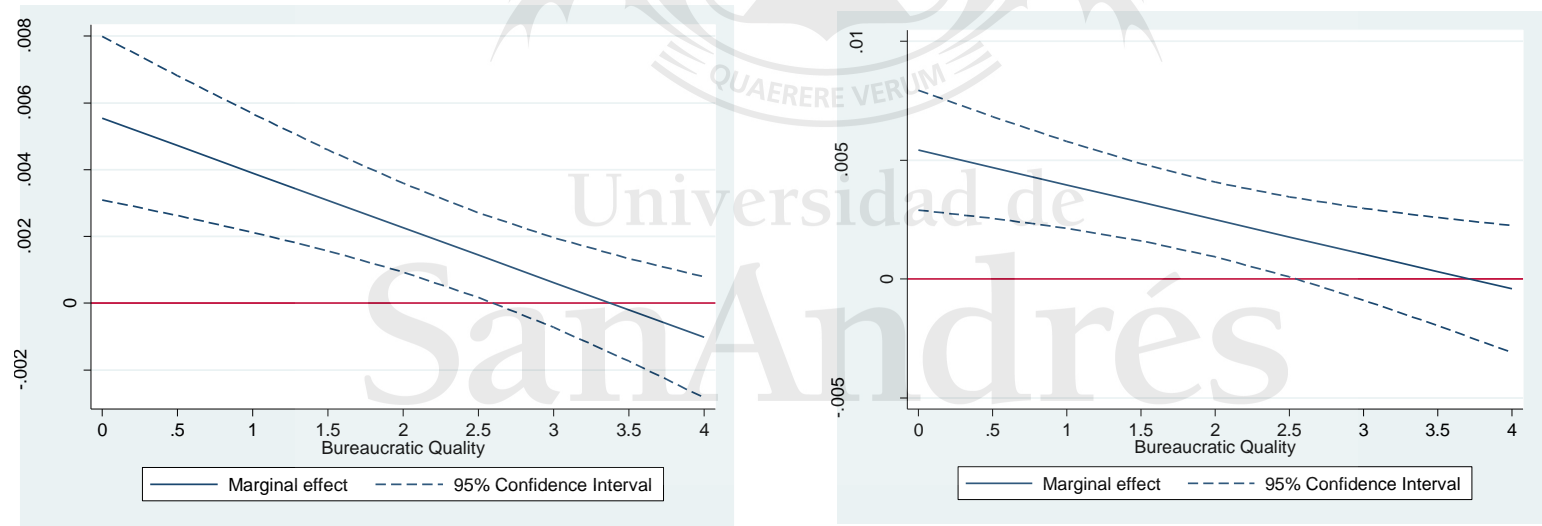

a. Column 3 of Table 2 in the main article.

b. Column 4 of Table 2 in the main article (TOT Volatility $50^{\text {th }}$ p.) 


\section{Results over time}

In order to check is our results are stable over time we run a series of cross-sections evaluating the dependent variable in the five-year periods $90-94,95-99$, and 00-04. While we obtain the same qualitative results, the intercept and slope of the conditional relationship change over time, particularly between the first two sub-periods. In the 1995-99 period, the intercept (the coefficient of openness) is smaller and the slope is shallower. This evidence may be consistent with a pattern in which there is learning and policy diffusion, which allows more countries to pursue more efficient policies. This evidence may serve as a first indication of why the statistical and economic significance of Rodrik's results has fallen over time.

Table 6.1. The Effects of Openness on Government Size over Time

\begin{tabular}{|c|c|c|c|c|c|c|}
\hline \multirow{2}{*}{ VARIABLES } & \multicolumn{6}{|c|}{ Log Government Consumption (\% of GDP) for the period: } \\
\hline & $1990-94$ & $1990-94$ & 1995-99 & $1995-99$ & 2000-04 & 2000-04 \\
\hline \multirow[t]{2}{*}{ Openness (t-1) } & 0.001 & $0.008 * * *$ & 0.000 & $0.004^{* * *}$ & 0.000 & $0.004 *$ \\
\hline & $(0.001)$ & $(0.002)$ & $(0.001)$ & $(0.001)$ & $(0.001)$ & $(0.002)$ \\
\hline Bureaucratic Quality (t-1) & & $0.261 * * *$ & & $0.176^{* * *}$ & & $0.160 * *$ \\
\hline & & $(0.052)$ & & $(0.057)$ & & $(0.078)$ \\
\hline \multirow[t]{2}{*}{ Openness (t-1) x Bureaucratic Quality (t-1) } & & $-0.003 * * *$ & & $-0.002 * * *$ & & $-0.001 *$ \\
\hline & & $(0.001)$ & & $(0.001)$ & & $(0.001)$ \\
\hline Observations & 103 & 103 & 103 & 103 & 103 & 103 \\
\hline Adjusted R-squared & 0.342 & 0.493 & 0.345 & 0.421 & 0.318 & 0.353 \\
\hline
\end{tabular}

Data are period averages for 1990-94, 1995-99, 2000-04, for the dependent variable (in t), and 1985-89, 1990-94, 199599, for the independent variables in (t-1); except for the controls which belong to the beginning of each period. Additional controls: log GDP per capita, log urbanization rate, and log dependency ratio all at the beginning of each period, and dummy variables for OECD, Sub-Saharan Africa, Latin America, East Asia, and Socialist countries.

Standard errors in parentheses. $* * * p<0.01, * * p<0.05, * p<0.1$ 
Figure 6.1. Marginal Effect of Trade Openness on Government Consumption along Bureaucratic Quality over Time

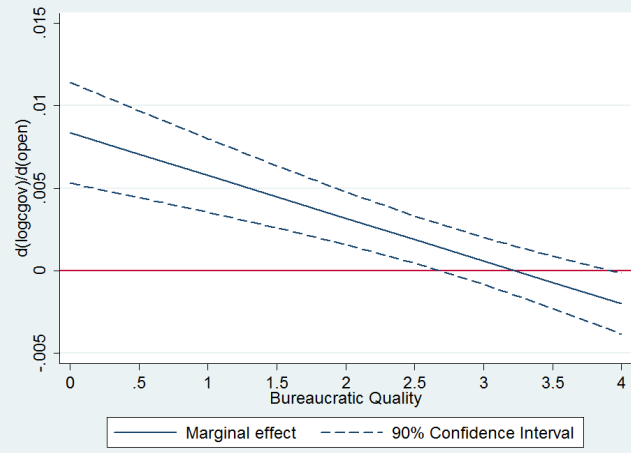

a. Column 2 of Table 6 (1985-89 - 1990-94)

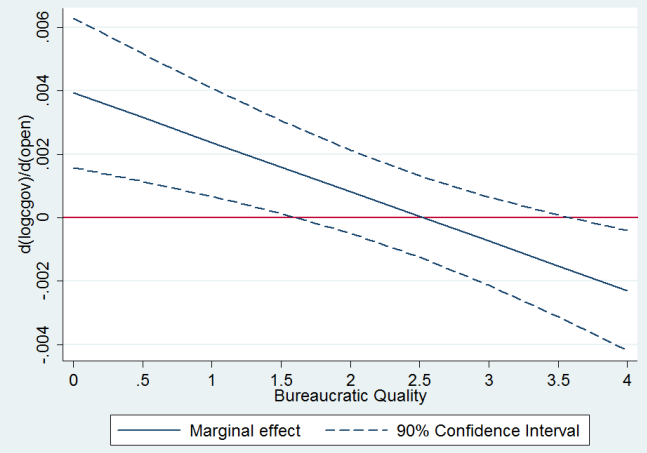

b. Column 4 of Table 6 (1990-94 - 1995-99) 


\section{Instrumental Variables: Expanded Set of Instruments}

The following tables present the results using the other instruments mentioned in the main body of our work, namely Persson and Tabellini's (2003) age of democracy (age) and its square, and a dummy variable for former colonies (ex-colony), Rockey's (2012) date of first democratic constitutions $(m c)$ and its square, Besley and Persson's (2009) measure of political stability (pol. stab), Acemoglu, Johnson and Robinson's (2001) measure of European settler mortality during colonization (settler mort.), Cruz and Keefer's (2013) programmatic parties variable (rlc_avg), and CCP's legislative oversight power (intexec) and judicial independence (judind) measure. 
Table 7.1. Second Stage Results: Instrumental Variables, Expanded Set of Instruments, Broad Sample

\begin{tabular}{|c|c|c|c|c|c|c|c|c|c|c|}
\hline \multirow{2}{*}{ VARIABLES } & \multicolumn{10}{|c|}{ Log Government Consumption (\% of GDP) 2000-05 } \\
\hline & (1) & (2) & (3) & (4) & $(5)$ & $(6)$ & (7) & (8) & (9) & (10) \\
\hline Openness $(\mathrm{t}-1)$ & 0.002 & 0.002 & 0.005 & $0.009 *$ & 0.004 & $0.008^{* * *}$ & -0.002 & $0.012^{* * *}$ & $0.019 * * *$ & $0.016 * * *$ \\
\hline Bureaucratic Quality (t-1) & $\begin{array}{l}(0.004) \\
0.016 \\
(0.113)\end{array}$ & $\begin{array}{l}(0.005) \\
0.139 \\
(0.120)\end{array}$ & $\begin{array}{l}(.005) \\
0.029 \\
(0.121)\end{array}$ & $\begin{array}{l}(0.005) \\
0.082 \\
(0.134)\end{array}$ & $\begin{array}{l}(0.003) \\
0.231^{* * *}\end{array}$ & $\begin{array}{l}(0.0011) \\
0.118\end{array}$ & $\begin{array}{l}(0.003) \\
0.152^{* * *}\end{array}$ & $\begin{array}{l}(0.004) \\
0.353^{* * *}\end{array}$ & $\begin{array}{l}(0.003) \\
0.278^{* * *}\end{array}$ & $\begin{array}{l}(0.003) \\
0.176 * *\end{array}$ \\
\hline Openness (t-1) x Bureaucratic Quality (t-1) & $\begin{array}{c}(0.113) \\
-0.000 \\
(0.001)\end{array}$ & $\begin{array}{l}(0.120) \\
-0.001 \\
(0.001)\end{array}$ & $\begin{array}{l}(0.121) \\
-0.001 \\
(0.001)\end{array}$ & $\begin{array}{c}(0.134) \\
-0.003^{* *} \\
(0.001)\end{array}$ & $\begin{array}{l}(0.025) \\
-0.001 \\
(0.001)\end{array}$ & $\begin{array}{c}(0.100) \\
-0.002^{* * *} \\
(0.000)\end{array}$ & $\begin{array}{c}(0.035) \\
0.000 \\
(0.001)\end{array}$ & $\begin{array}{c}(0.129) \\
-0.004^{* * *} \\
(0.001)\end{array}$ & $\begin{array}{c}(0.016) \\
-0.005 * * * \\
(0.001)\end{array}$ & $\begin{array}{c}(0.073) \\
-0.005 * * \\
(0.001)\end{array}$ \\
\hline Expanded Controls & Yes & Yes & Yes & Yes & Yes & Yes & Yes & $\begin{array}{c}0.484 \\
\text { Yes }\end{array}$ & Yes & Yes \\
\hline Excluded Instruments & $\begin{array}{c}\text { age, } \\
\text { age*openness }\end{array}$ & $\begin{array}{c}\text { age, age*openness, } \\
\text { age^^}, \\
\text { age } 2{ }^{*} \text { openness }\end{array}$ & mc & $\begin{array}{c}\mathrm{mc}, \mathrm{mc}^{*} \text { openness, } \\
\mathrm{mc} \mathrm{c}^{\wedge} 2 \\
\mathrm{mc^{ \wedge } 2 *} \text { openness }\end{array}$ & $\begin{array}{c}\text { ex-colony, } \\
\text { ex-colony*openness }\end{array}$ & $\begin{array}{l}\text { pol. stab, pol. } \\
\text { stab*openness }\end{array}$ & $\begin{array}{l}\text { settler mort., } \\
\text { settler mort.*openness }\end{array}$ & $\begin{array}{c}\text { rlc_avg, } \\
\text { rlc_avg*openness }\end{array}$ & $\begin{array}{c}\text { intexec, } \\
\text { intexec*openness }\end{array}$ & $\begin{array}{c}\text { judind } \\
\text { judind*openness }\end{array}$ \\
\hline Observations & 64 & 64 & 77 & 77 & 77 & 75 & 34 & 75 & 34 & 34 \\
\hline Adjusted R-squared & 0.529 & 0.595 & 0.449 & 0.426 & 0.494 & 0.485 & 0.207 & 0.484 & 0.755 & 0.758 \\
\hline
\end{tabular}


Table 7.2. First Stage Results: Instrumental Variables, Expanded Set of Instruments, Broad Sample

\begin{tabular}{|c|c|c|c|c|c|c|c|c|c|c|}
\hline FIRST-STAGE VARIABLES & $\begin{array}{l}\text { Bur. Quality } \\
\text { (1) }\end{array}$ & $\begin{array}{c}\text { Open *Bur } \\
(2)\end{array}$ & $\begin{array}{l}\text { Bur. Quality } \\
\text { (3) }\end{array}$ & $\begin{array}{c}\text { Open *Bur } \\
(4)\end{array}$ & $\begin{array}{l}\text { Bur. Quality } \\
\text { (5) }\end{array}$ & $\begin{array}{c}\begin{array}{c}\text { Open *Bur } \\
(6)\end{array} \\
\end{array}$ & $\begin{array}{c}\text { Bur. Quality } \\
\text { (7) }\end{array}$ & $\begin{array}{c}\text { Open *Bur } \\
(8)\end{array}$ & $\begin{array}{c}\text { Bur. Quality } \\
\text { (9) }\end{array}$ & $\begin{array}{c}\text { Open *Bur } \\
(10)\end{array}$ \\
\hline \multirow[t]{2}{*}{ age } & 0.065 & $-8.231^{*}$ & $0.420^{* *}$ & 3.977 & & & & & & \\
\hline & $(0.049)$ & $(4.179)$ & $(0.189)$ & (15.845) & & & & & & \\
\hline \multirow[t]{2}{*}{ age $x$ Openness $(\mathrm{t}-1)$} & -0.000 & $0.153^{* *}$ & -0.001 & 0.191 & & & & & & \\
\hline & $(0.001)$ & $(0.059)$ & $(0.002)$ & $(0.248)$ & & & & & & \\
\hline \multirow[t]{2}{*}{$a g e^{\wedge} 2$} & & & $-0.041^{*}$ & -1.323 & & & & & & \\
\hline & & & $(0.021)$ & (1.777) & & & & & & \\
\hline age $2 \times 2$ Openness $(t-1)$ & & & $\begin{array}{l}0.000 \\
(0.000)\end{array}$ & $\begin{array}{l}-0.007 \\
(0.030)\end{array}$ & & & & & & \\
\hline \multirow[t]{2}{*}{$m c$} & & & & & 0.129 & $\begin{array}{r}-9.263 \\
-9.2601\end{array}$ & 0.538 & -29.729 & & \\
\hline & & & & & $(0.083)$ & $(9.540)$ & $(0.366)$ & (36.695) & & \\
\hline \multirow[t]{2}{*}{$\mathrm{mc} \times$ Openness $(\mathrm{t}-1)$} & & & & & -0.001 & $0.304 * *$ & -0.002 & $1.133^{*}$ & & \\
\hline & & & & & $(0.001)$ & $(0.128)$ & $(0.005)$ & $(0.678)$ & & \\
\hline \multirow[t]{2}{*}{$m c^{\wedge 2}$} & & & & & & & $\begin{array}{l}-0.090 \\
-0.075)\end{array}$ & $\begin{array}{l}5.223 \\
(8245)\end{array}$ & & \\
\hline & & & & & & & $\begin{array}{c}(0.075) \\
0.000\end{array}$ & $\begin{array}{l}(8.245) \\
-0.200\end{array}$ & & \\
\hline$m c^{\wedge} 2 \times$ Openness $(t-1)$ & & & & & & & $(0.001)$ & $(0.158)$ & & \\
\hline Ex-colony & & & & & & & & & $0.604^{*}$ & $100.063^{* * *}$ \\
\hline Ex-colony $x$ Openness (t-1) & & & & & & & & & $\begin{array}{l}-0.008^{*} \\
(0.005)\end{array}$ & $\begin{array}{l}-1.2711^{* *} \\
(0.492)\end{array}$ \\
\hline Expanded Controls & Yes & Yes & Yes & Yes & Yes & Yes & Yes & Yes & Yes & Yes \\
\hline Excluded Instruments & age, age*openness & age, age*openness & $\begin{array}{l}\text { age, age*openness, } \\
\text { age^ } 2 \text {, age^ } 2 * \text { openness }\end{array}$ & $\begin{array}{l}\text { age, age*openness, } \\
\text { age } 2 \text {, age } 2^{\wedge} \text { openness }\end{array}$ & $\mathrm{mc}, \mathrm{mc}$ *openness & $\mathrm{mc}, \mathrm{mc}$ *openness & $\begin{array}{c}\mathrm{mc}, \mathrm{mc}^{*} \text { openness, } \\
\mathrm{mc}^{\wedge} \text {, } \\
\mathrm{mc}^{\wedge} 2^{*}{ }^{*} \text { openness }\end{array}$ & $\begin{array}{c}\mathrm{mc}, \mathrm{mc}^{*} \text { openness, } \\
\mathrm{mc}^{\wedge} \text {, } \\
\mathrm{mc}^{\wedge} 2^{*} \text { openness }\end{array}$ & $\begin{array}{l}\text { ex-colony, } \\
\text { ex-colony*openness }\end{array}$ & $\begin{array}{c}\text { ex-colony, } \\
\text { ex-colony*openness }\end{array}$ \\
\hline Observations & 64 & 64 & 64 & 64 & 77 & 77 & 77 & 77 & 77 & 77 \\
\hline Adjusted R-squared & 0.771 & 0.945 & 0.798 & 0.946 & 0.755 & 0.920 & 0.755 & 0.922 & 0.757 & 0.918 \\
\hline \multirow{2}{*}{$\begin{array}{l}F \\
\text { Prob>F }\end{array}$} & 1.700 & 3.410 & 3.080 & 3.170 & 1.350 & 4.130 & 1.540 & 3.090 & 1.630 & 4.380 \\
\hline & 0.194 & 0.041 & 0.025 & 0.022 & 0.266 & 0.021 & 0.202 & 0.022 & 0.204 & 0.017 \\
\hline \multicolumn{11}{|l|}{$\begin{array}{l}\text { A-P } F \text { test of weak excluded instruments } \\
F\end{array}$} \\
\hline $\mathrm{F}$ & 3.320 & 6.820 & 3.330 & 3.270 & 2.700 & 7.620 & 1.800 & 3.360 & 0.030 & 0.080 \\
\hline Prob $>F$ & 0.075 & 0.012 & 0.027 & 0.029 & 0.105 & 0.008 & 0.157 & 0.025 & 0.859 & 0.772 \\
\hline
\end{tabular}


Table 7.2., continued

\begin{tabular}{|c|c|c|c|c|c|c|c|c|c|c|}
\hline FIRST-STAGE VARIABLES & $\begin{array}{l}\text { Bur. Quality } \\
\text { (11) }\end{array}$ & $\begin{array}{l}\text { Open * Bur } \\
\text { (12) }\end{array}$ & $\begin{array}{c}\text { Bur. Quality } \\
\text { (13) }\end{array}$ & $\begin{array}{l}\text { Open * Bur } \\
\text { (14) }\end{array}$ & $\begin{array}{l}\text { Bur. Quality } \\
\text { (15) }\end{array}$ & $\begin{array}{l}\text { Open * Bur } \\
\text { (16) }\end{array}$ & $\begin{array}{l}\text { Bur. Quality } \\
\text { (17) }\end{array}$ & $\begin{array}{l}\text { Open * Bur } \\
\text { (18) }\end{array}$ & $\begin{array}{l}\text { Bur. Quality } \\
\text { (19) }\end{array}$ & $\begin{array}{l}\text { Open * Bur } \\
\text { (20) }\end{array}$ \\
\hline Pol. Stab & $\begin{array}{l}-0.726 \\
(0.769)\end{array}$ & $\begin{array}{l}-50.622 \\
(72.132)\end{array}$ & & & & & & & & \\
\hline Pol. Stab x Openness (t-1) & $\begin{array}{c}0.002 \\
(0.011)\end{array}$ & $\begin{array}{c}0.161 \\
(1.057)\end{array}$ & & & & & & & & \\
\hline Settler mort. & & & $\begin{array}{c}0.069 \\
(0.174)\end{array}$ & $\begin{array}{l}-20.347 \\
(20.609)\end{array}$ & & & & & & \\
\hline Settler mort. x Openness (t-1) & & & $\begin{array}{l}-0.006 \\
(0.181)\end{array}$ & $\begin{array}{c}-1.673 \\
(12.752)\end{array}$ & & & & & & \\
\hline$r l c \_a v g$ & & & & & $\begin{array}{l}0.973^{* *} \\
(0.478)\end{array}$ & $\begin{array}{c}34.244 \\
(62.621)\end{array}$ & & & & \\
\hline rlc_avg $x$ Openness (t-1) & & & & & $\begin{array}{l}-0.006 \\
(0.005)\end{array}$ & $\begin{array}{c}0.221 \\
(0.779)\end{array}$ & & & & \\
\hline intexec & & & & & & & $\begin{array}{l}-0.237 \\
(0.333)\end{array}$ & $\begin{array}{l}-37.118 \\
(27.500)\end{array}$ & & \\
\hline intexec $x$ Openness $(t-1)$ & & & & & & & $\begin{array}{c}0.001 \\
(0.004)\end{array}$ & $\begin{array}{l}0.177 \\
(0.308)\end{array}$ & & \\
\hline judind & & & & & & & & & $\begin{array}{l}-0.534 \\
(0.445)\end{array}$ & $\begin{array}{c}10.408 \\
(42.453)\end{array}$ \\
\hline judind $x$ Openness $(t-1)$ & & & & & & & & & $\begin{array}{l}0.006 \\
(0.004)\end{array}$ & $\begin{array}{l}-0.541 \\
(0.673)\end{array}$ \\
\hline Expanded Controls & Yes & Yes & Yes & Yes & Yes & Yes & Yes & Yes & Yes & Yes \\
\hline Excluded Instruments & $\begin{array}{c}\text { pol. stab, } \\
\text { pol.stab*openness }\end{array}$ & $\begin{array}{c}\text { pol.stab, } \\
\text { pol.stab*openness }\end{array}$ & $\begin{array}{l}\text { settler mort., } \\
\text { settler mort.*openness }\end{array}$ & $\begin{array}{l}\text { settler mort., } \\
\text { settler mort.*openness }\end{array}$ & $\begin{array}{c}\text { rlc_avg, } \\
\text { rlc_avg*openness }\end{array}$ & $\begin{array}{c}\text { rlc_avg1, } \\
\text { rlc_avg*openness }\end{array}$ & $\begin{array}{c}\text { intexec, } \\
\text { intexec*openness }\end{array}$ & $\begin{array}{c}\text { intexec, } \\
\text { intexec*openness }\end{array}$ & $\begin{array}{l}\text { judind, } \\
\text { judind*openness }\end{array}$ & $\begin{array}{c}\text { judind, } \\
\text { judind*openness }\end{array}$ \\
\hline Observations & 75 & 75 & 34 & 34 & 75 & 75 & 34 & 34 & 34 & 34 \\
\hline Adjusted R-squared & 0.765 & 0.916 & 0.807 & 0.954 & 0.770 & 0.915 & 0.867 & 0.973 & 0.853 & 0.973 \\
\hline $\mathrm{F}$ & 1.380 & 0.940 & 0.090 & 0.520 & 3.060 & 3.010 & 0.970 & 1.470 & 0.990 & 1.180 \\
\hline Prob $>F$ & 0.259 & 0.395 & 0.913 & 0.600 & 0.054 & 0.057 & 0.398 & 0.257 & 0.391 & 0.330 \\
\hline A-P $F$ test of weak excluded instrum & & & & & & & 0020 & 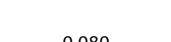 & & \\
\hline 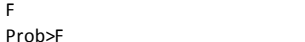 & $\begin{array}{l}0.000 \\
0.984\end{array}$ & $\begin{array}{l}0.000 \\
0.989\end{array}$ & $\begin{array}{l}0.000 \\
0.946\end{array}$ & $\begin{array}{l}0.080 \\
0.780\end{array}$ & $\begin{array}{l}2.340 \\
0.132\end{array}$ & 0.870 & $\begin{array}{l}0.020 \\
0.891\end{array}$ & $\begin{array}{l}0.080 \\
0.784\end{array}$ & $\begin{array}{l}1.220 \\
0.283\end{array}$ & $\begin{array}{l}1.890 \\
0.186\end{array}$ \\
\hline
\end{tabular}




\section{Robustness results - Placebos}

In spite of the checks we have performed on the measure of bureaucratic quality, and on the robustness of our empirical work, it could still be possible that our measure could be "picking up something else." That is, that our measure is proxying some other underlying process which is more relevant for explaining the process of compensation. One option could be that we are proxying inequality (Gini coefficient), or fractionalization in society (ethnolinguistic fractionalization index). In the first case, it would be the case that those countries with higher inequality are the ones that decide to compensate the most; alternatively, those which are more fractionalized are the ones that would tend to isolate the different groups from external shocks to avoid conflicts. Other options could be that the level of democracy matters (Gastil), or the institutional constraints (Checks), which may make it harder for countries to adjust unless they have a large public sector already in place. We bring these hypotheses to the data but we find that none of them produce the same conditional effects. The coefficient of the interaction between openness and the placebo variable turns out not significant in each and every one of the regressions. 
Table 8.1. Placebo Results

\begin{tabular}{|c|c|c|c|c|c|c|c|c|c|c|}
\hline \multirow[b]{2}{*}{ VARIABLES } & \multicolumn{10}{|c|}{ Log Government Consumption (\% of GDP) 2000-05 } \\
\hline & (1) & (2) & (3) & (4) & (5) & $(6)$ & (7) & (8) & (9) & (10) \\
\hline Openness (t- 1 ) & $\begin{array}{c}0.005^{* * *} \\
(0.002)\end{array}$ & $\begin{array}{l}0.004^{* *} \\
(0.002)\end{array}$ & $\begin{array}{c}0.007 \\
(0.004)\end{array}$ & $\begin{array}{c}0.009 \\
(0.006)\end{array}$ & $\begin{array}{c}0.001 \\
(0.002)\end{array}$ & $\begin{array}{c}0.002 \\
(0.002)\end{array}$ & $\begin{array}{c}0.001 \\
(0.001)\end{array}$ & $\begin{array}{l}0.004^{* *} \\
(0.002)\end{array}$ & $\begin{array}{l}-0.0004 \\
(0.002)\end{array}$ & $\begin{array}{c}0.003 \\
(0.003)\end{array}$ \\
\hline Bureaucratic Quality (t-1) & $\begin{array}{c}0.174 * * * \\
(0.058)\end{array}$ & $\begin{array}{c}0.099 \\
(0.073)\end{array}$ & & & & & & & & \\
\hline Openness (t-1) x Bureaucratic Quality (t-1) & $\begin{array}{c}-0.002^{* * *} \\
(0.001)\end{array}$ & $\begin{array}{l}-0.001 \\
(0.001)\end{array}$ & & & & & & & & \\
\hline Gini (t-1) & & & $\begin{array}{c}0.015 \\
(0.009)\end{array}$ & $\begin{array}{l}0.017^{*} \\
(0.010)\end{array}$ & & & & & & \\
\hline Openness (t-1) x Gini (t-1) & & & $\begin{array}{c}-0.0001 \\
(0.00009)\end{array}$ & $\begin{array}{c}-0.0001 \\
(0.0001)\end{array}$ & & & & & & \\
\hline Ethnolinguistic frac. (t-1) & & & & & $\begin{array}{l}-0.021 \\
(0.274)\end{array}$ & $\begin{array}{c}0.031 \\
(0.283)\end{array}$ & & & & \\
\hline Openness (t-1) x Ethnolinguistic frac. (t-1) & & & & & $\begin{array}{c}0.00004 \\
(0.003)\end{array}$ & $\begin{array}{l}-0.001 \\
(0.003)\end{array}$ & & & & \\
\hline Checks (t-1) & & & & & & & $\begin{array}{c}0.013 \\
(0.036)\end{array}$ & $\begin{array}{c}0.033 \\
(0.039)\end{array}$ & & \\
\hline Openness (t-1) x Checks (t-1) & & & & & & & $\begin{array}{c}-0.0002 \\
(0.0004)\end{array}$ & $\begin{array}{l}-0.001 \\
(0.001)\end{array}$ & & \\
\hline Gastil (t-1) & & & & & & & & & $\begin{array}{l}-0.032 \\
(0.041)\end{array}$ & $\begin{array}{l}-0.013 \\
(0.047)\end{array}$ \\
\hline Openness (t-1) x Gastil (t-1) & & & & & & & & & $\begin{array}{c}-0.0002 \\
(0.0004)\end{array}$ & $\begin{array}{l}0.0001 \\
(0.001)\end{array}$ \\
\hline Constant & $\begin{array}{l}1.795^{*} \\
(0.981)\end{array}$ & $\begin{array}{l}2.506^{* *} \\
(1.197)\end{array}$ & $\begin{array}{c}1.199 \\
(1.504)\end{array}$ & $\begin{array}{c}2.188 \\
(1.687)\end{array}$ & $\begin{array}{l}2.020^{*} \\
(1.052)\end{array}$ & $\begin{array}{l}2.728^{* *} \\
(1.253)\end{array}$ & $\begin{array}{l}1.840^{*} \\
(1.049)\end{array}$ & $\begin{array}{l}2.418^{*} \\
(1.237)\end{array}$ & $\begin{array}{c}1.413 \\
(1.040)\end{array}$ & $\begin{array}{l}2.641^{* *} \\
(1.299)\end{array}$ \\
\hline Sample & Broad & Rodrik's & Broad & Rodrik's & Broad & Rodrik's & Broad & Rodrik's & Broad & Rodrik's \\
\hline $\begin{array}{l}\text { Observations } \\
\text { Adjusted R-squared }\end{array}$ & 127 & 101 & 91 & 70 & 124 & 99 & 125 & 100 & 126 & 101 \\
\hline Adjusted R-squared & 0.350 & 0.357 & 0.256 & 0.282 & 0.297 & 0.340 & 0.298 & 0.358 & 0.332 & 0.343 \\
\hline
\end{tabular}

